\title{
Evidence of an elevated source of nucleation based on model simulations and data from the NIFTy experiment
}

\author{
P. Crippa ${ }^{1}$, T. Petäjä ${ }^{2}$, H. Korhonen ${ }^{3}$, G. S. El Afandi ${ }^{4}$, and S. C. Pryor ${ }^{1}$ \\ ${ }^{1}$ Atmospheric Science Program, College of Arts and Sciences, Indiana University, Bloomington, IN 47405, USA \\ ${ }^{2}$ Department of Physics, University of Helsinki, Helsinki, Finland \\ ${ }^{3}$ Finnish Meteorological Institute, Kuopio Unit, Kuopio, Finland \\ ${ }^{4}$ College of Agricultural, Environment and Nutrition Sciences - College of Engineering, Tuskegee University, Tuskegee, \\ AL 36088, USA \\ Correspondence to: P. Crippa (pcrippa@indiana.edu)
}

Received: 5 March 2012 - Published in Atmos. Chem. Phys. Discuss.: 9 May 2012

Revised: 9 August 2012 - Accepted: 26 August 2012 - Published: 10 September 2012

\begin{abstract}
New particle formation has been observed at a number of ground-based measurement sites. Prior research has provided evidence that this new particle formation, while observed in the near-surface layer, is actually occurring in atmospheric layers above the surface and appears to be focused in or close to the residual layer formed by the nocturnal inversion. Here, we present both observations and modeling for southern Indiana which support this postulate. Based on simulations with a detailed aerosol dynamics model and the Weather Research and Forecasting model, along with data from ground-based remote sensing instruments and detailed gas and particle phase measurements, we show evidence that (i) the maximum rate change of ultrafine particle concentrations as observed close to the surface is always preceded by breakdown of the nocturnal inversion and enhancement of vertical mixing and (ii) simulated particle size distributions exhibit greatest accord with surface observations during and subsequent to nucleation only when initialized with a particle size distribution representative of clear atmospheric conditions, rather than the in situ (ground-level) particle size distribution.
\end{abstract}

\section{Introduction and objectives}

Particle nucleation has been observed with high frequency at a geographically diverse suite of ground-based measurement sites (Kulmala et al., 2011) and plays a key role in determining the ambient particle size distribution (Spracklen et al.,
2006), but the controls and limitations on nucleation occurrence and growth remain uncertain. Key uncertainties pertain, in part, to mechanistic deconvolution of the chemical and physics controls and include questions regarding variation of nucleation intensity and mechanisms with height, and specifically whether nucleation occurs principally within the atmospheric boundary layer or is initiated at or close to the residual layer (or free troposphere) (Boulon et al., 2011; Crumeyrolle et al., 2010; Pierce et al., 2012; Stratmann et al., 2003; Wehner et al., 2010). Indications of a link between the occurrence and intensity of nucleation and boundary layer dynamics is provided by observations that enhancement of turbulent kinetic energy, associated with entrainment and development of the boundary layer, is frequently observed just prior to the appearance of newly formed particles in the mixed layer (Nilsson et al., 2001; Pryor et al., 2011). Further, balloon-borne observations during the SATURN experiment near Leipzig in Germany provided evidence that prior to the break-up of the nocturnal inversion nucleation was focused on the residual layer and, subsequent to erosion of the inversion and growth of the boundary layer, nucleation was observed throughout the planetary boundary layer (Stratmann et al., 2003; Wehner et al., 2007). Additional evidence for an elevated source of nucleated particles at continental sites in Europe was provided by data collected near Cabauw in the Netherlands in the IMPACT field campaign (Wehner et al., 2010). In that research vertical profiles of particle size distributions were taken in a helicopter borne package and the evolution of the boundary layer was observed using a lidar 
system. As in the SATURN experiment, analysis of the IMPACT measurements led the authors to infer that nucleation likely started higher in the atmosphere and the newly formed particles were subsequently mixed downward (Wehner et al., 2010). The IMPACT authors postulate that the strong vertical variability of new particle formation is a result of enhanced turbulence and non-linear mixing in specific layers which resulted in supersaturation of precursor gases coupled with vertical heterogeneity of in situ aerosol concentrations and thus variations in the condensational sink leading to enhancement or suppression of nucleation. It should be noted that not all investigators have found evidence for an elevated nucleation source. Data collected using an instrumented aircraft and micro-light flown over the Hyytiälä site during 28 March 2003 are indicative of a surface-based particle source, with subsequent vertical dispersion as the mixedlayer grew (Laaksonen et al., 2008). Here we examine this issue further using: (i) data from the Nucleation In ForesTs (NIFTy) experiment in southern Indiana in conjunction with simulations conducted using the Weather Research and Forecasting (WRF) model and (ii) a novel approach based on the application of a parameterized multi-component particle model (i.e. the University of Helsinki Multicomponent Aerosol (UHMA) model). Specifically we use the UHMA model to examine the sensitivity of nucleation and growth to the prevailing chemical and physical environmental conditions (i.e. abundance of nucleation precursors and condensational sink) in order to theorize the region of the atmosphere in which nucleation is initiated. On the basis of the sensitivity analysis conducted using as input to the model conditions observed close to the ground versus those associated with an elevated source of nucleation we infer that nucleation is initiated aloft. Supporting evidence for these assertions is drawn from ground-based particle size distribution measurements, observed and modeled profiles of the meteorological state parameters and lidar backscatter measurements.

\section{Methods}

\section{$2.1 \quad$ NIFTy}

During the Nucleation In ForesTs (NIFTy) experiment, conducted between 5 and 31 May 2008, particle physical and chemical properties, gas phase concentrations and meteorological parameters of state were measured at three locations along an $80 \mathrm{~km}$ transect in southern Indiana from Indianapolis in the northeast to the small college town of Bloomington in the southwest (Pryor et al., 2011). The primary measurements used herein were collected during the later portion of the NIFTy experiment (14-27 May) at the Morgan Monroe State Forest (MMSF) tower site, centrally located along this transect, when the most complete set of measurements was available. A Scanning Mobility Particle Sizer (SMPS) system from TSI Inc. (SMPS 3936) and a
Fast Mobility Particle Sizer (FMPS 3091) (TSI, Inc.) were deployed at MMSF to measure simultaneously particle size distributions from a height of $46 \mathrm{~m}$ (above a canopy of 28 $\mathrm{m})$. The SMPS system comprised an Electrostatic Classifier (Model 3080), a nano-DMA (Model 3085) and a Condensation Particle Counter (Model 3786), and measured number concentrations in 80 logarithmically-spaced size channels from 3.22 to $105.5 \mathrm{~nm}$. The FMPS reported number concentrations in 32 logarithmically-spaced size channels from 6.04 to $523.3 \mathrm{~nm}$. Measured particle concentrations from both instruments were corrected using the experimentally derived tubing particle transmission efficiencies presented in Pryor et al. (2010). Discontinuous measurements of ammonia $\left(\mathrm{NH}_{3}\right)$ concentrations above the canopy were made using a Wet Effluent Diffusion Denuder (WEDD) system (Pryor et al., 2001). Thirty-minute average concentrations of $\mathrm{SO}_{2}$ and $\mathrm{H}_{2} \mathrm{SO}_{4}$ were measured below the forest canopy using a TECO (model 43S) monitor and a Chemical Ionization Mass Spectrometer (CIMS) (Eisele and Tanner, 1993; Mauldin et al., 2003; Petäjä et al., 2009). The CIMS was also operated to provide estimated hydroxyl radical $(\mathrm{OH})$ concentrations close to the ground during 23-29 May. These measurements were used to derive a composite $30 \mathrm{~s}$ diurnal profile of $\mathrm{OH}$ concentrations during event and non-event days for use in the UHMA modeling. VOC concentrations were measured at the canopy top in six approximately 2-h intervals starting at 09:00 (LST) on multi-sorbent cartridges at flow rate of $27 \mathrm{ml} \mathrm{min}^{-1}$ following the EPA Method TO-17 and analyzed for isoprene, $\alpha$-pinene, limonene, cumene (isopropylbenzene), benzene, toluene, ethyl benzene, o-, m-, and pxylene. In order to make composites of multiple event days in this analysis, following the approach used in Pryor et al. (2011), all times were converted to a normalized scale in which the time is presented relative to the maximum gradient (i.e. rate change) in $10 \mathrm{~nm}$ particle number concentrations.

Meteorological conditions at the site were measured using micrometeorological equipment installed on this AmeriFlux tower, a scanning doppler lidar (Natural Power ZephIR lidar), a Vaisala tethersonde and a Vaisala ceilometer (CL31) (see Pryor et al., 2011 for a full description of the instrumentation deployed at MMSF).

Long-term measurements at the MMSF site indicate evidence of elevated concentrations of ultra-fine particles $\left(D_{\mathrm{p}}\right.$ : 6-30 nm) on approximately 1 day in 5 (Pryor et al., 2010), with a highest frequency in May, consistent with observed high concentrations of ultra-fine particles on nearly half of all sampling days during NIFTy (Table 1) (Pryor et al., 2011).

\subsection{UHMA model}

The UHMA model is a box-model containing parameterizations of the dynamics of multicomponent particles including nucleation (based on parameterization of binary, ternary and kinetic nucleation), condensation, coagulation and dry deposition (Korhonen et al., 2004). In this study the particle 
Table 1. Classification of event days at the MMSF site during the NIFTy experiment for 14-27 May based on the subjective classification of (Boy and Kulmala, 2002). The hour of maximum rate change of $10 \mathrm{~nm}$ particle concentrations (start hour) is provided in local standard time (LST). Observed nucleation intensities $\left[\mathrm{cm}^{-3}\right]$, computed as the number of particles with diameter between 10 and $30 \mathrm{~nm}$ in the two hours of highest concentration, are shown in the 4th column. The final three columns show model simulation results setting 250 sections and initializing the model with the measured particle size distribution (measured PSD) and clear atmospheric conditions (clear case) wherein the PSD is as described by (Seigneur et al., 1986).

\begin{tabular}{|c|c|c|c|c|c|c|}
\hline \multirow[b]{2}{*}{ Day } & \multicolumn{3}{|c|}{ Observations SMPS (and FMPS) } & \multicolumn{3}{|c|}{ Simulations } \\
\hline & Event & $\begin{array}{l}\text { Start } \\
\text { hour } \\
\text { (LST) }\end{array}$ & $\begin{array}{l}\text { Nucleation } \\
\text { Intensity }\left[\mathrm{cm}^{-3}\right] \\
\text { from the SMPS }\end{array}$ & $\begin{array}{l}\text { Initialized } \\
\text { with measured } \\
\text { PSD }\end{array}$ & $\begin{array}{l}\text { Nucleation } \\
\text { Intensity }\left[\mathrm{cm}^{-3}\right] \\
\text { (measured PSD) }\end{array}$ & $\begin{array}{l}\text { Nucleation } \\
\text { Intensity }\left[\mathrm{cm}^{-3}\right] \\
\text { (clear case) }\end{array}$ \\
\hline 14 & Non-event (Non-event) & Non-event & Non-event & Non-event & Non-event & Non-event \\
\hline 15 & Non-event (Non-event) & Non-event & Non-event & Non-event & Non-event & Non-event \\
\hline 16 & $\mathrm{C}(\mathrm{C})$ & 9 & $3.58 \times 10^{4}$ & A & $1.48 \times 10^{5}$ & $1.87 \times 10^{5}$ \\
\hline 17 & $\mathrm{~A}(\mathrm{~A})$ & 9 & $1.06 \times 10^{5}$ & $\mathrm{~A}$ & $4.13 \times 10^{4}$ & $1.54 \times 10^{5}$ \\
\hline 18 & $\mathrm{C}(\mathrm{C})$ & 10 & $5.17 \times 10^{4}$ & $\mathrm{C}$ & $3.65 \times 10^{1}$ & $1.20 \times 10^{5}$ \\
\hline 19 & $\mathrm{~A}(\mathrm{~A})$ & 9 & $6.95 \times 10^{4}$ & $\mathrm{C}$ & $7.12 \times 10^{1}$ & $1.80 \times 10^{5}$ \\
\hline 20 & $\mathrm{~B}(\mathrm{~B})$ & 13 & $1.18 \times 10^{4}$ & $\mathrm{~A}$ & $2.10 \times 10^{3}$ & $9.06 \times 10^{4}$ \\
\hline 21 & $A(A)$ & 8 & $2.47 \times 10^{4}$ & A & $1.88 \times 10^{2}$ & $9.17 \times 10^{4}$ \\
\hline 22 & $\mathrm{~A}(\mathrm{~A})$ & 9 & $4.90 \times 10^{4}$ & A & $5.37 \times 10^{4}$ & $1.41 \times 10^{5}$ \\
\hline 23 & Non-event (Non-event) & Non-event & Non-event & Non-event & Non-event & Non-event \\
\hline 24 & $\mathrm{~A}(\mathrm{~A})$ & 10 & $2.22 \times 10^{4}$ & A & $3.26 \times 10^{4}$ & $1.84 \times 10^{5}$ \\
\hline 25 & $\mathrm{~A}(\mathrm{C})$ & 9 & $5.37 \times 10^{4}$ & A & $3.83 \times 10^{3}$ & $1.92 \times 10^{5}$ \\
\hline 26 & Non-event (Non-event) & Non-event & Non-event & Non-event & Non-event & Non-event \\
\hline 27 & Non-event (Non-event) & Non-event & Non-event & Non-event & Non-event & Non-event \\
\hline
\end{tabular}

size distribution (PSD) is treated using a fixed sectional discretization of the size distribution in the modified version of the hybrid grid (Jacobson and Turco, 1995), which does not require any assumption regarding the PSD and allows us to describe accurately the variability associated with field measurements (Spracklen et al., 2005). Since only condensed core compounds need to be split among size sections, numerical diffusion is reduced (Jacobson and Turco, 1995). Herein we employ the UHMA model using the following assumptions:

- The temporal variation of boundary layer depth (and thus box model volume in which concentrations are assumed to be homogeneous) is simulated using a pseudo-sinusoidal profile evolving between 06:00 and 21:00 (LST) with maximum of $1000 \mathrm{~m}$ and minimum of $300 \mathrm{~m}$ (this minimum is maintained throughout the nighttime hours) based on data obtained from a tethersonde system deployed during NIFTy and confirmed based on simulations conducted using the WRF model. All other physical state parameters (e.g. temperature and humidity) are input hourly to the model based on observed conditions at $46 \mathrm{~m}$.

- Particle removal. Within the original UHMA model dry deposition processes are described by a semiempirical parameterization validated for the boreal forest in Hyytiälä, Finland (Rannik et al., 2003). Deposition velocities over deciduous forests have been shown to be lower than those measured over boreal forests (Pryor et al., 2009), thus we implemented a physical parameterization of dry deposition (Slinn, 1982; Pryor and Binkowski, 2004) constrained to match observed sizeresolved particle deposition velocities of sub- $100 \mathrm{~nm}$ diameter particles as measured at the MMSF site (Pryor et al., 2009). No removal by wet deposition was parameterized.

- A simplified gas phase chemical mechanism was implemented following the work of (Boy et al., 2005) (Table 2 and Table 3) and was solved using the Euler Backward Iterative approach. Observed concentrations of the inorganic gases $\left(\mathrm{SO}_{2}\right.$ and $\left.\mathrm{NH}_{3}\right)$ and condensable organic gases were provided at hourly resolution to the model. Because we did not have direct observations of semivolatile organic compounds, the concentration of the condensable organics was estimated from the observations of isoprene, a-pinene, cumene, limonene, benzene, toluene, ethyl-benzene, (m,p)-xylene, and (o)-xylene using Fractional Aerosol Coefficients (FAC) (Grosjean, 1992). The concentration of biogenic compounds was observed to be approximately twice that for the anthropogenic VOCs (Pryor et al., 2011), thus while only one lumped reaction was implemented for the anthropogenic VOCs, the reaction of biogenics with both $\mathrm{OH}$ and ozone was included (see Table 2). It is acknowledged that this approach neglects factors such as the 
Table 2. Chemical reactions implemented within the UHMA model (Reference $1=($ Hertel et al., 1993), $2=($ Boy et al., 2006$), 3=($ Seinfeld and Pandis, 2006), $4=$, Simpson et al., 1997). Second order rate constants are expressed in [ppb $\mathrm{pp}^{-1} \mathrm{~s}^{-1}$ for a temperature of $298 \mathrm{~K}$. Photolysis rate constants are expressed in $\mathrm{s}^{-1}$ and computed as $J=l \times(\cos \Theta)^{m} \times e^{-n \times \sec \Theta}$, wherein $\Theta$ is the solar zenith angle. Typical peak values of photolysis rate constants for the MMSF site during a clear sky day in May are reported.

\begin{tabular}{lll}
\hline Reaction & Rate constant & Reference \\
\hline $\mathrm{SO}_{2}+\mathrm{OH}=\mathrm{H}_{2} \mathrm{SO}_{4}+\mathrm{HO}_{2}$ & $2.50 \times 10^{-2}$ & 1 \\
$\mathrm{NO}_{2}+\mathrm{OH}=\mathrm{HNO}_{3}$ & $2.72 \times 10^{-1}$ & 1 \\
$\mathrm{OH}+\mathrm{CO}=\mathrm{HO}_{2}$ & $6.67 \times 10^{-3}$ & 1 \\
$\mathrm{O}_{3}+\mathrm{OH}=\mathrm{HO}_{2}$ & $1.67 \times 10^{-3}$ & 1 \\
$\mathrm{HCHO}+\mathrm{OH}=\mathrm{HO}_{2}+\mathrm{CO}$ & $2.50 \times 10^{-1}$ & 1 \\
$\mathrm{HO}_{2}+\mathrm{HO}_{2}=\mathrm{H}_{2} \mathrm{O}_{2}+\mathrm{O}_{2}$ & $6.91 \times 10^{-2}$ & 1 \\
$\mathrm{Biogenic}_{2}$ organics $+\mathrm{OH}=$ products & 1.32 & 3 \\
Anthropogenic organics $+\mathrm{OH}=$ products & $1.53 \times 10^{-1}$ & 1 \\
$\alpha-$ pinene $+\mathrm{O}_{3}=$ products & $2.13 \times 10^{-6}$ & 3 \\
$\mathrm{H}_{2}+\mathrm{OH}=\mathrm{HO}_{2}+\mathrm{H}_{2} \mathrm{O}$ & $1.65 \times 10^{-1}$ & 2 \\
$\mathrm{HO}_{2}+\mathrm{NO}=\mathrm{OH}+\mathrm{NO}_{2}$ & $2.00 \times 10^{2}$ & 3 \\
$\mathrm{HO}_{2}+\mathrm{O}_{3}=\mathrm{OH}+2 \mathrm{O}$ & $4.76 \times 10^{-2}$ & 3 \\
$\mathrm{O}_{3}=0.2 \mathrm{OH}+0.8 \mathrm{O}_{3}(\mathrm{P})$ & $3.05 \times 10^{-4}$ & 4 \\
$\mathrm{HCHO}^{2}=2 \mathrm{HO}+\mathrm{CO}_{2}$ & $3.21 \times 10^{-4}$ & 4 \\
\hline
\end{tabular}

Table 3. Input concentrations [ppb] to the chemical mechanism based on Boy and Kulmala (2002) and typical spring values measured in Southern Indiana by the Indiana Department of Environmental Management.

\begin{tabular}{ll}
\hline Compound & Concentration [ppb] \\
\hline $\mathrm{O}_{3}$ & 30 \\
$\mathrm{NO}_{2}$ & 5 \\
$\mathrm{NO}$ & 2.5 \\
$\mathrm{CO}$ & 800 \\
$\mathrm{HCHO}$ & 10 \\
$\mathrm{CH}_{4}$ & 1900 \\
$\mathrm{H}_{2}$ & 500 \\
$\mathrm{HO}_{2}$ & $3.7 \times 10^{-3}$ \\
\hline
\end{tabular}

relationship with condensed mass (Griffin et al., 2003), but it is applied here to broadly represent the potential for the production of oxidation products with low volatility that might partition into the particle phase.

- Comprehensive evaluations of nucleation parameterizations (Zhang et al., 2010a, b; Sihto et al., 2006) have illustrated the challenge of selecting a theoretically appropriate nucleation parameterization and the huge range of variation of model skill when predictions based on differing parameterizations are compared to observed number concentrations (e.g. up to 3 orders of magnitude variations for the Aitken and accumulation mode). In order to select which of the nucleation parameterizations was optimal for the simulations in southern Indiana, we used the approach of Sihto et al. (2006) and Kuang et al. (2008) to examine the functional rela- tionship between ultra-fine particle nucleation rate and observed sulfuric acid concentrations $\left(\left[\mathrm{H}_{2} \mathrm{SO}_{4}\right]\right)$. If nucleation can be described using the activation approach, then the formation rate of new particles should scale linearly with $\left[\mathrm{H}_{2} \mathrm{SO}_{4}\right]$. If the nucleation process is best described by the kinetic approach then the formation rate will tend to scale with the square of $\left[\mathrm{H}_{2} \mathrm{SO}_{4}\right]$, while if it follows the ternary nucleation theory, with the critical cluster comprising $\mathrm{NH}_{3}, \mathrm{H}_{2} \mathrm{SO}_{4}$ and water molecules, the exponent should exceed 3 (Sihto et al., 2009). Thus:

$J_{(1 \mathrm{~nm})}=K \times\left[\mathrm{H}_{2} \mathrm{SO}_{4}\right]^{n}$

where $n$ represents the number of sulfuric acid molecules in each critical cluster. The best linear fit of the logarithm of the nucleation rate and the logarithm of sulfuric acid concentration for class A events during NIFTy provided a value of $n$ of 1.78 and $K$ of around $10^{-14}$ (Fig. 1). $J_{1}$ was computed based on (Kuang et al., 2008):

$$
\begin{aligned}
J_{1}(t) & =J_{10}(t+\Delta t) \times \exp \left[\frac{1}{2} \times \frac{A_{\mathrm{FUCHS}}}{\mathrm{GR}_{1-10}} \times \sqrt{\frac{48 k_{\mathrm{B}} T}{\pi^{2} \rho}}\right. \\
& \left.\times\left(\frac{1}{\sqrt{D_{\mathrm{p} 1}}}-\frac{1}{\sqrt{D_{\mathrm{p} 10}}}\right)\right]
\end{aligned}
$$

where $J_{10}$ was derived from the measured PSD from the SMPS and the median Fuchs surface area of the preexisting particles during $t+\Delta t$ was computed as: 


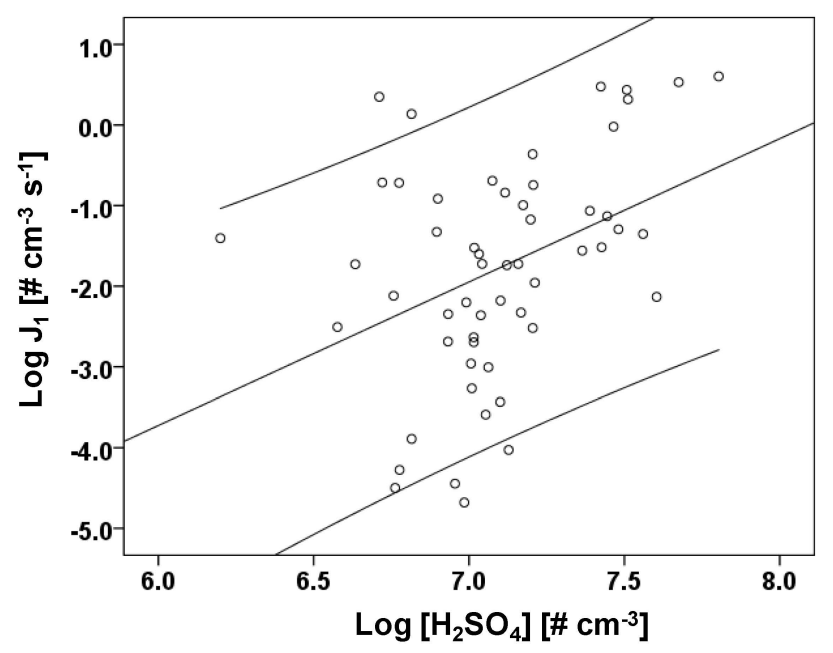

Fig. 1. Relationship between the base 10 logarithm of sulfuric acid concentrations $\left[\mathrm{cm}^{-3}\right]$ and the base 10 logarithm of the nucleation rate of $1 \mathrm{~nm}$ particles [ $\mathrm{cm}^{-3} \mathrm{~s}^{-1}$ ] during nucleation hours of class A events. The estimated regression coefficients are statistically significant, giving a regression line of $\log _{10} J_{1}=-14.39 \times$ $\log _{10}\left[\mathrm{H}_{2} \mathrm{SO}_{4}\right]^{1.78}$. The $90 \%$ confidence intervals for $K([-21.28$, $-7.51])$ and $n([0.81,2.75])$ are also shown.

$$
\begin{aligned}
A_{\mathrm{FUCHS}} & =\frac{4}{3} \pi \times \int_{D_{\mathrm{p} 6}}^{D_{\mathrm{p} 10}} D_{\mathrm{p}}^{2} \\
& \times\left(\frac{K n+K n^{2}}{1+1.71 K n+1.33 K n^{2}}\right) n\left(D_{\mathrm{p}}\right) \mathrm{d} D_{\mathrm{p}}
\end{aligned}
$$

where $n\left(D_{\mathrm{p}}\right)$ is the number concentration of particles of diameter $D_{\mathrm{p}}$.

The Knudsen number is defined as:

$K n=\frac{2 \lambda}{D_{\mathrm{p}}}$

where $\lambda$ is assumed to be $100 \mathrm{~nm}$ (Kuang et al., 2008), the particle density, $\rho$ is $1.3 \mathrm{~kg} \mathrm{~m}^{-3}$ and $k_{\mathrm{B}}$ is the Boltzmann constant. An average $\Delta t$ of $0.5 \mathrm{~h}$ was estimated from the time shift required to match the measured sulfuric acid concentrations with the $6-10 \mathrm{~nm}$ diameter average particle number concentrations. Based on the results of the analysis of the nucleation rate as a function of sulfuric acid concentrations we chose to apply a kinetic approach to nucleation where the prefactor $K$ is derived from the basic kinetic theory, assuming nucleation to be limited by the collision rate of sulfuric acid molecules (Seinfeld and Pandis, 2006), rather than estimated from observations (Sihto et al., 2006).
We need to acknowledge the regression fit between $\log \left[\mathrm{H}_{2} \mathrm{SO}_{4}\right]$ and $\log \left(J_{1}\right)$ is highly sensitive to the fitting time length since a fit conducted only on the duration of each nucleation event would provide higher slope values (Kuang et al., 2008). Because of the relative low temporal resolution of the available sulfuric acid measurements we fitted the model over a larger time span than has been previously used.

- Initial particle size distribution. For the base case simulations, the model was initialized using the PSD measured by the FMPS at midnight (LST) of each simulated day (14-27 May 2008). In order to reduce the sensitivity to measurement uncertainty in each size bin, the data from the FMPS were fitted to three log-normal modes (see the example in Fig. 2). The geometric mean diameter, standard deviation and number concentration from these modes were then used to derive the initial number concentration in each of the model size sections. The model was then run for $24 \mathrm{~h}$ and evaluated over the same time period.

The time-step of the simulations was set to $10 \mathrm{~s}$. A sensitivity analysis was undertaken to assess model performance as a function of the number of sections used to describe the PSD, but for all other simulations, 250 sections equally spaced in a logarithmic scale in the range of diameters between $3 \mathrm{~nm}$ and $10 \mu \mathrm{m}$, were used to match the discretization of the PSD for the sub 100-nm particles from the SMPS operated at MMSF in order to facilitate the evaluation of the model fit to the data.

Since the UHMA model has been previously theoretically validated (Korhonen et al., 2004), herein we use statistical metrics not to evaluate the model per se but as a diagnostic tool. Three primary metrics of model performance are used:

a. The presence, absence and "type" of nucleation event as defined using a subjective event classification (Boy and Kulmala, 2002):

class A: a new sudden particle mode appears in the diameter range below $25 \mathrm{~nm}$ and it persists and grows for more than $1 \mathrm{~h}$.

class B: a new particle mode is present but it is not visible at the smallest measured diameters. The computation of the growth rate may be uncertain because of high variations in the mode number concentration.

class C: a new particle mode is present but does not show a clear growth.

The day was defined as non-event if the aforementioned conditions are not met (see Table 1 for a summary of the observed data from the SMPS and FMPS in terms of the event classification).

b. The skill of the UHMA model in predicting the particle number size distribution is quantified by metrics such as 

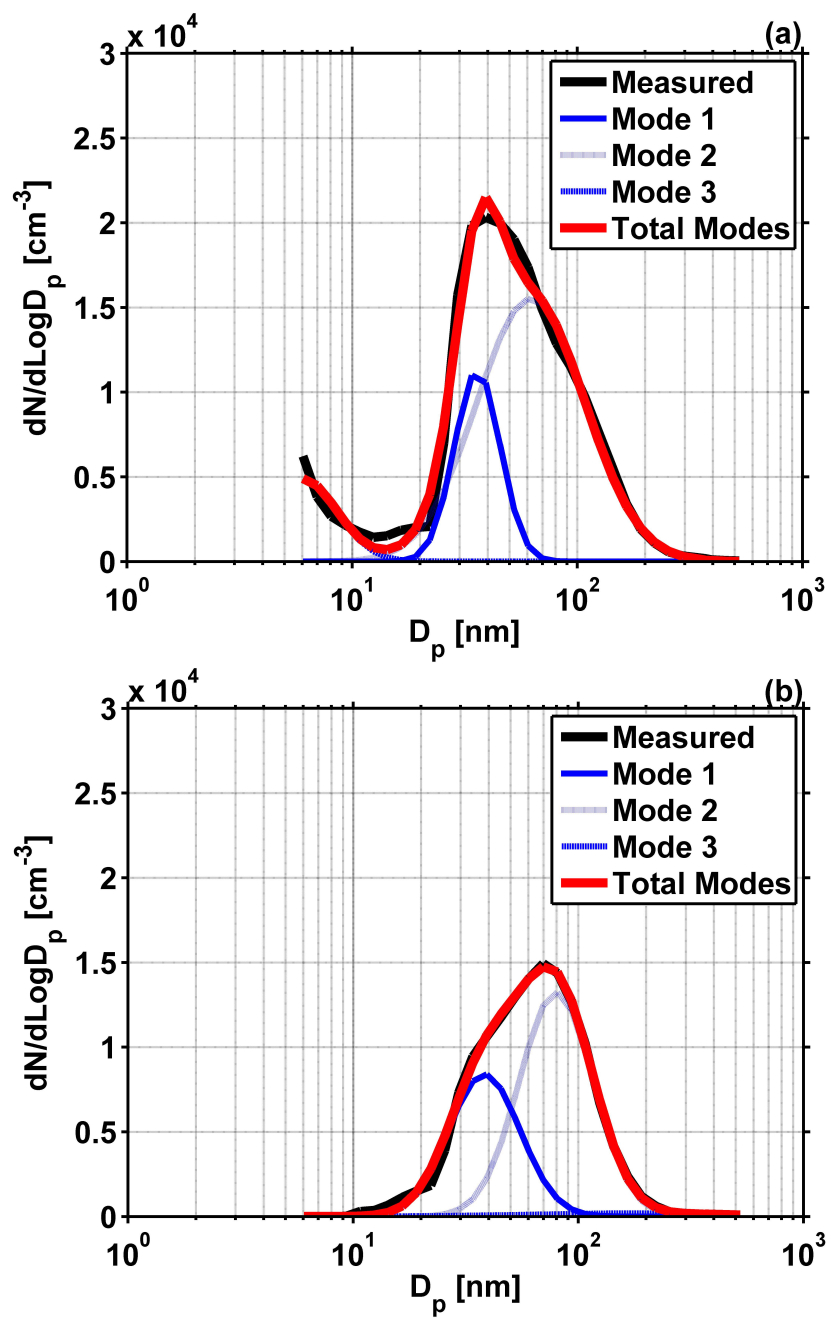

Fig. 2. Fit of the initial PSD to a three lognormal function using data measured by the FMPS at 00:00 LST for (a) an example Aevent day (19 May) and (b) a non-event day (26 May).

nucleation intensity, the growth rate and the timing of the peak number concentration. Nucleation intensity is quantified as the total number of particles with diameter between 10 and $30 \mathrm{~nm}$ during the two hours with the highest total number concentration:

Intensity $=\sum_{h=1}^{2} \sum_{D_{\mathrm{p}}=10}^{30} N_{h, D_{\mathrm{p}}}$

The growth rate is defined as the rate at which the number geometric mean diameter $\left(\overline{D_{\mathrm{gN}}}\right)$ in the nucleation mode $(6-30 \mathrm{~nm})$ evolves:

$\ln \overline{D_{\mathrm{gN}}}=\frac{\sum_{j=6}^{30} n_{j} \times \ln D_{j}}{N_{6-30}}$ where $\ln \bar{D}_{\mathrm{gN}}$ is the value of $\ln D$ weighted according to the number of particles in that size interval, $n_{j}$ is the number of particles in a group whose diameters are centered around $D_{j}$ and $N_{6-30}$ is the total number of particles in the diameter range of $6-30 \mathrm{~nm}$. The growth rate is computed fitting a first order polynomial to the number geometric mean diameters occurring in the three hours subsequent to the minimum $\overline{D_{\mathrm{gN}}}$. The time difference $(\Delta t)$ between the occurrence of maximum observed and simulated number concentration of particles of size 6-30 nm was also computed:

$$
\Delta t=t\left(\max N_{6-30}^{\mathrm{obs}}\right)-t\left(\max N_{6-30}^{\mathrm{sim}}\right)
$$

\subsection{WRF simulations}

The Weather Research and Forecasting model Version 3 (WRFV3), applied using the physics schemes listed in Table 4 , was used to simulate meteorological conditions during 1126 May 2008 over a parent domain $(324 \times 274$ grid cells with a spatial resolution of $9 \mathrm{~km})$ and a nested domain $(310 \times 259$ grid cells with a spatial resolution of $3 \mathrm{~km}$ ) (Fig. 3). The model was run using the Advanced Research WRF (ARW) solver in the non-hydrostatic mode with 35 vertical levels and initialized with lateral boundary conditions as simulated by the North American Mesoscale Model (NAM). The land cover data were specified from the USGS 24-category data at a resolution of $3.7 \mathrm{~km}$ and $0.9 \mathrm{~km}$ for the parent and nested domain respectively. The WRF simulations were conducted principally to examine the vertical evolution of the planetary boundary layer and thus the primary physics scheme of interest to the current work is the PBL package. The MellorYamada-Janjic scheme (a TKE-based 2.5-level closure) was selected because it is relatively computationally efficient, has been widely used in prior research and has been demonstrated to generate relatively representative temperature profiles and PBL heights in applications elsewhere (Hu et al., 2010).

\section{Results}

\subsection{Evidence for an elevated source of nucleation from observations}

As described below, observations of meteorological parameters at the MMSF site support the hypothesis of nucleation initiation above the surface with subsequent entrainment of the freshly nucleated particles into the mixed layer.

Turbulence intensity as measured with the ZephIR lidar indicates a strong link between the occurrence of high concentrations of ultra-fine particles at the MMSF site and boundary layer dynamics. The greatest increase in the number concentration of 6-10 nm particles occurs approximately one hour prior to the peak of nucleation intensity at $46 \mathrm{~m}$ during class 


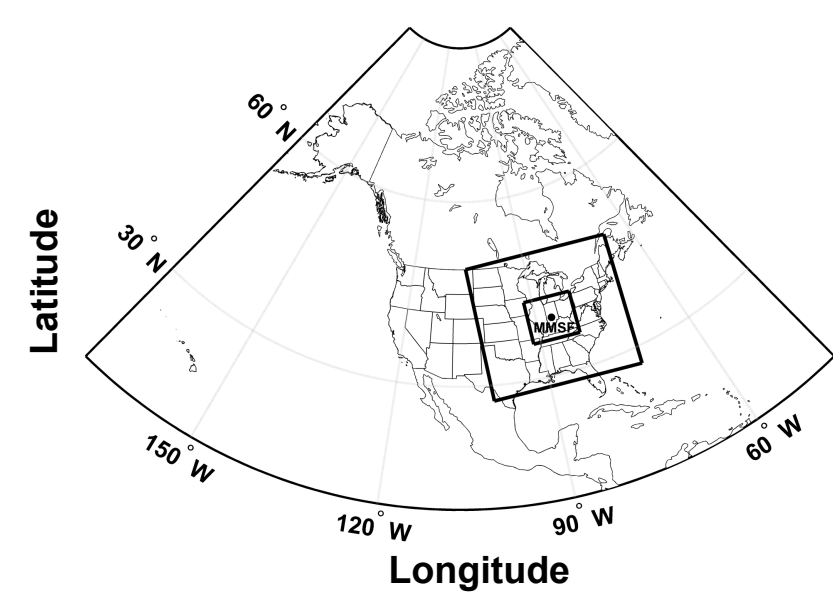

Fig. 3. Parent and nested domain simulated by WRF imposing a spatial resolution of $9 \mathrm{~km}$ and $3 \mathrm{~km}$ respectively. The location of the MMSF site is also shown.

Table 4. Physics schemes (Skamarock et al., 2008) adopted for the WRF simulations.

\begin{tabular}{ll}
\hline Physics option & Adopted scheme \\
\hline Microphysics & WRF Single-Moment 6-class \\
Longwave Radiation & Rapid Radiative Transfer Model (RRTM) \\
Shortwave Radiation & Dudhia \\
Surface layer & Eta \\
Land Surface & Noah Land Surface Model \\
Planetary boundary layer & Mellor-Yamada-Janjic \\
Cumulus parameterizations & Kain-Fritsch \\
\hline
\end{tabular}

A events (Fig. 4a). Nearly simultaneously turbulence intensity rapidly increases from low values throughout the lowest $300 \mathrm{~m}$ of the atmosphere (representative of a stable nocturnal atmosphere) to more turbulent conditions associated with erosion of the nocturnal inversion and development of a fully mixed planetary boundary layer (Fig. 4b). Thus erosion of the nocturnal inversion and increased vertical mixing always preceded the maximum concentration of ultra-fine particles and was observed to precede the maximum rate change of ultrafine particle concentrations by approximately $0.5 \mathrm{~h}$.

Further evidence supporting the hypothesis of an elevated source of nucleation is provided by the analysis of the condensational sink (CS) (Kulmala et al., 2001; Dal Maso et al., 2002) measured in the surface layer (at $46 \mathrm{~m}$ ) during event class A days. The CS is a metric quantifying the role of preexisting particles in removing condensable vapors from the atmosphere, thus a high CS is expected to suppress nucleation. As in research conducted elsewhere, there is a lack of correspondence between the observed CS in near-surface measurements just prior to the largest rate change of ultrafine particles and the concentration of ultrafine particles (Fig. 5) (Boulon et al., 2011). This also supports our speculation of an elevated initiation of nucleation.
The Vaisala ceilometer has a wavelength of $910 \mathrm{~nm}$ and thus shows strongest response to the accumulation mode particles that also tend to dominate the PSD and thus the condensational sink. The ceilometer backscatter measurements were processed following the approach of Stratmann et al. (2003), to examine evidence for elevated atmospheric layers with relatively low aerosol loading (i.e. low backscatter) and thus more favorable for nucleation occurrence (i.e. lower CS). In this approach the backscatter signals from each $20 \mathrm{~m}$ increment in each $5 \mathrm{~min}$ period from each day is normalized to the average backscatter at that height over the period 06:0012:00 (LST) (Fig. 6a-c). The backscatter profiles were integrated with vertical temperature profiles derived from simulations with the WRF model (Fig. 6) to examine the presence of a clear inversion and residual layer and to link the erosion of this layer to the appearance of elevated concentrations of ultrafine particles. A couple of hours prior to nucleation appearance in the surface layer, event class A days are always characterized by a strong temperature inversion with a base located at approximately $400 \mathrm{~m}$ (Fig. 6g). This inversion is much weaker during event class B and class C days (Fig. 6h) and completely absent during non-event days which are usually characterized by greater cloud cover (Fig. 6i). During event days, at the time newly formed particles are detected close to the surface, the nocturnal inversion is almost completely eroded. Moreover the relatively low elevation of the base of the residual layer (i.e. 600-700 m), coupled with intense mixing phenomena due to boundary layer dynamics, may favor the advection of new particles formed aloft into the mixed layer. Combining the vertical profiles of temperature with the relative backscatter signal derived from ceilometer data provides direct evidence of boundary layer dynamics and mixing processes. The ceilometer data indicate that on event class A days there was a clear evidence for a low backscatter layer associated with the inversion and residual layer (Fig. 6a). Just prior to the maximum rate change of $10 \mathrm{~nm}$ particles in the surface observations the inversion is eroded (Fig. 6d), during the transition to a fully mixed layer with high particle number concentrations. This transition often occurs simultaneously with, or earlier than, detection of substantial numbers of sub 10-nm particles detected close to the ground, which supports our hypothesis of particle entrainment from aloft.

Indirect evidence of nucleation being initiated aloft may be derived by examining the concentrations of the smallest detected particles during event class A days at the MMSF site. The ratio between the number concentration of $3 \mathrm{~nm}$ and $6 \mathrm{~nm}$ particles in the hour of maximum $6 \mathrm{~nm}$ particle concentrations (computed after applying the empirical transmission efficiency correction presented in Pryor et al., 2010) is on average $60 \%$ and thus is not sufficient to explain the observed $6 \mathrm{~nm}$ particle concentrations. The low concentrations of $3 \mathrm{~nm}$ particles might be related to limitations of the deployed instrument and the experimental setup but may also reflect early aging (i.e. growth by condensation and coagulation) of 

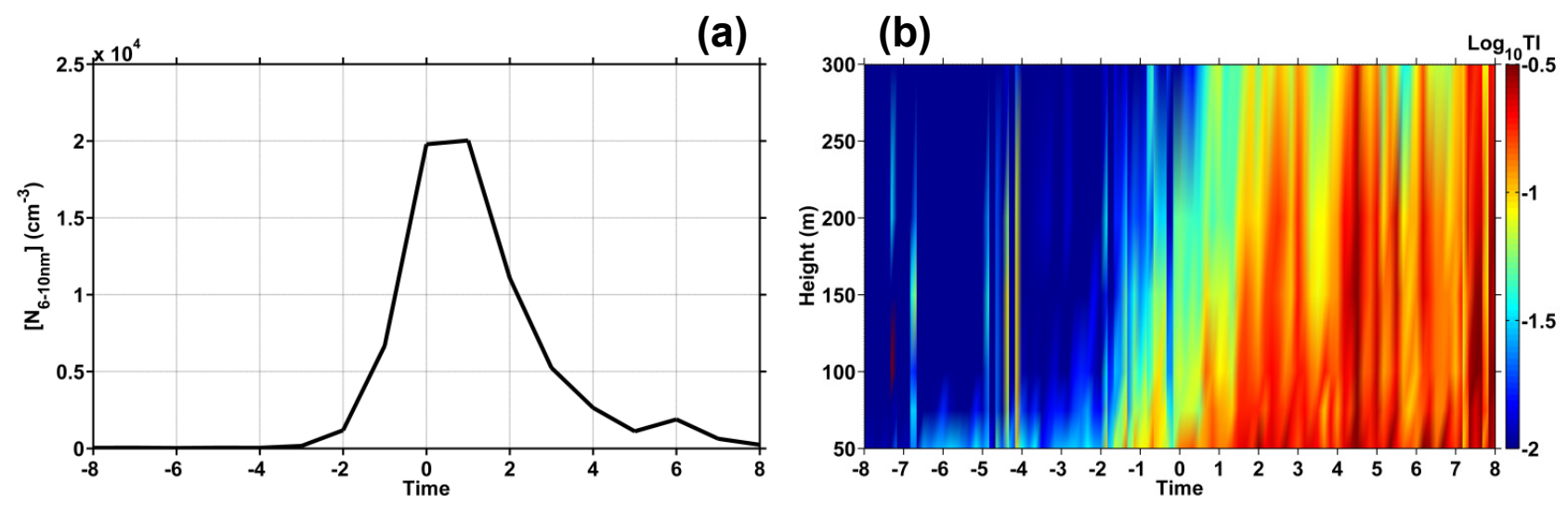

Fig. 4. (a) Mean 6-10 $\mathrm{nm}$ particle number concentrations $\left(\mathrm{cm}^{-3}\right)$ and (b) $\log _{10}$ of turbulence intensity estimated from the $10 \mathrm{~min}$ average ZephIR lidar measurements during event class A days. The time coordinate is expressed relative to the hour the maximum rate change of $10 \mathrm{~nm}$ particle concentrations was observed.

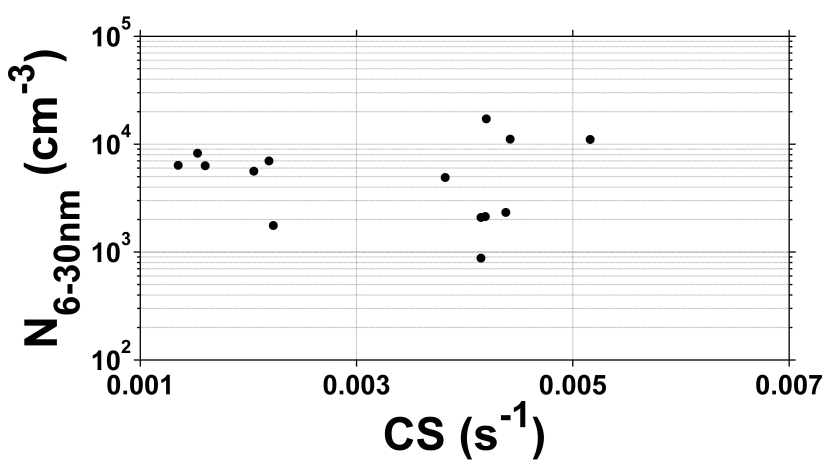

Fig. 5. Scatterplot of condensational sink (CS) $\left(\mathrm{s}^{-1}\right)$ and $D_{\mathrm{p}}=6-$ $30 \mathrm{~nm}$ particle number concentrations $\left(\mathrm{cm}^{-3}\right)$. CS is computed for all event days during NIFTy for the period $1 \mathrm{~h}$ prior to the maximum rate change of $10 \mathrm{~nm}$ particles.

freshly nucleated particles formed elsewhere from the sampling site as also speculated by Pierce et al. (2012). Following the logic presented in Birmili and Wiedensohler (2000), the presence of a closed contour in the particle number size distribution profile (see Fig. 7) is also indicative of non-local nucleation (i.e. that the particles being observed were formed earlier - in this case in an elevated layer). However, it should be acknowledged that a closed contour in this type of depiction of the PSD can also arise due to vapor condensation on an in situ particle population (Lehtinen and Kulmala, 2003).

\subsection{Evidence for an elevated source of atmospheric particles derived from model analyses}

A key consideration in evaluating any particle dynamics model is the sensitivity of the model to the description of the particle size distribution (Zhang et al., 1999). Indeed, reconciling the need for computational efficiency and adequate representation of the PSD is a key factor for implementing particle dynamics within regional and global climate models (Spracklen et al., 2006). A model sensitivity analysis to the size distribution discretization was conducted to define the optimum number of sections as a function of model performance and computational time (Table 5). The results show little sensitivity to the number of sections for higher number of sections (i.e. for simulations conducted using 300 sections rather than 250), hence 250 sections (over the whole simulated range of diameters: i.e. between $3 \mathrm{~nm}$ and $10 \mu \mathrm{m}$ ) were selected to match the size resolution of the SMPS operated at MMSF and thus has 80 sections in the size range 3-105 nm). However, it is worthy of note that based on our sensitivity analyses it appears that model skill improves only slightly setting more than 80 bins, thus given the computational time required by 250 sections is around nine times longer than assuming 80 sections, fewer than 250 sections may be used for longer term simulations.

When driven by measured sulfur dioxide concentrations and initialized using the observed PSD at midnight (LST) on each individual day, the UHMA model correctly simulates the occurrence or absence of nucleation (Table 1). However, these simulations indicate a clear systematic underprediction of the growth rate (Table 5 and Fig. 8) and typically an underestimation of nucleation intensity (Table 1). Further there is a marked offset in the timing of the maximum concentration of particle numbers for $D_{\mathrm{p}}=6-10 \mathrm{~nm}$ (Table 5). There are a number of possible causes for these systematic biases since the simulated particle number concentrations are determined by the balance between formation processes (the nucleation rate scales with the square of sulfuric acid concentrations) and removal processes (dry deposition and condensational sink). The kinetic nucleation approach was identified to be the dominant nucleation mechanism and since the dry deposition algorithm has been reformulated according to a physically based data-constrained description, thus we examined three other possible causal 
(a)

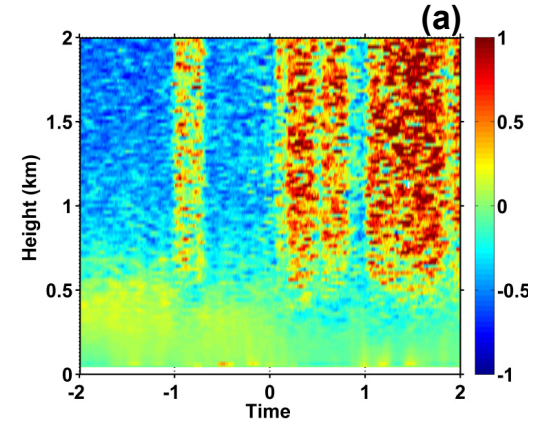

(b)

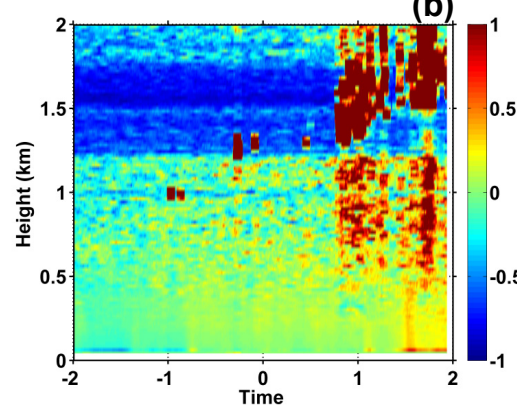

(c)

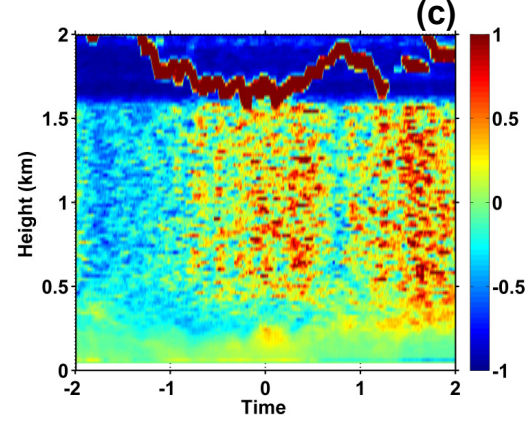

(d)

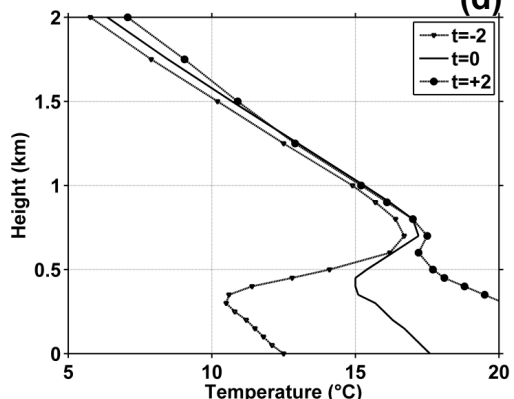

(e)

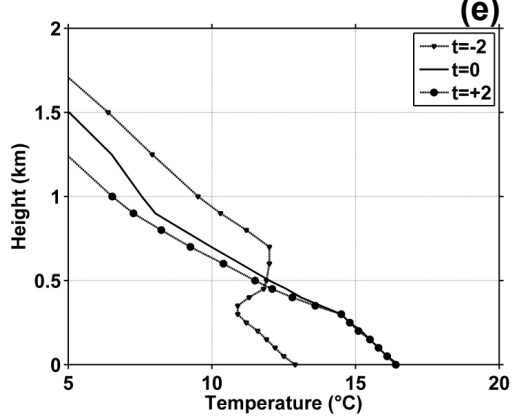

(f)

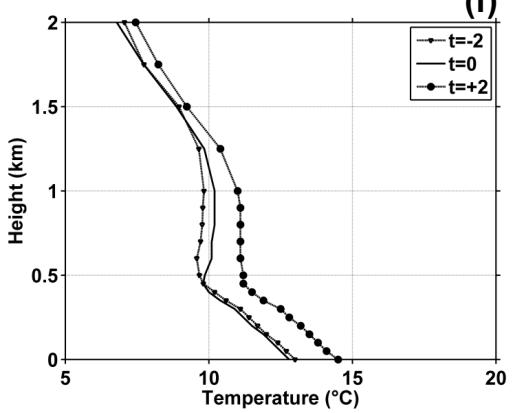

(g)

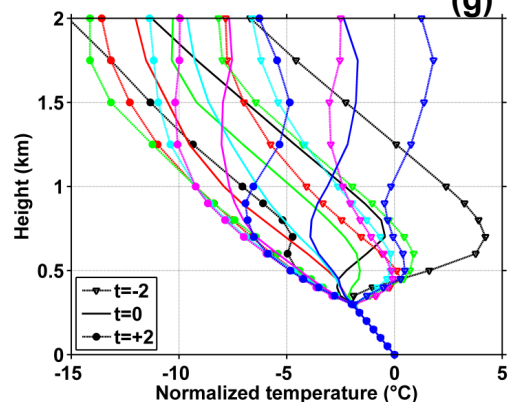

(h)

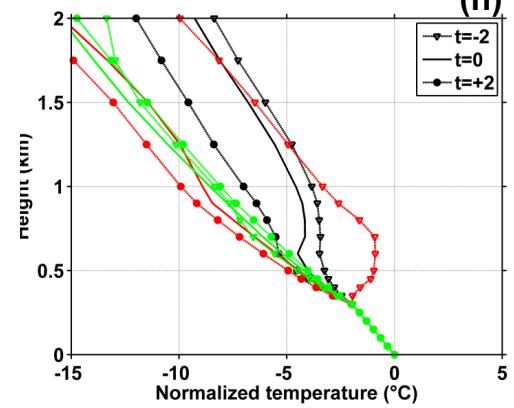

(i)

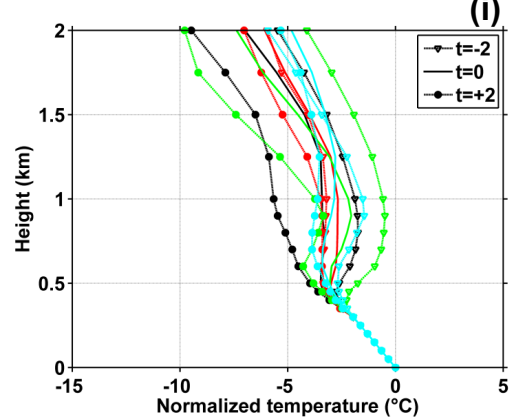

Fig. 6. Examples of relative backscatter signal computed from ceilometers data and vertical temperature profiles $\left({ }^{\circ} \mathrm{C}\right)$ simulated by WRF during a class A event (17 May) (a, d), class C event (18 May) (b, e), and non-event (23 May) (c, f) for times $t$ normalized relative to the hour of maximum rate change of $10 \mathrm{~nm}$ particle number concentrations. The relative backscatter $b_{\text {rel }}$ is defined according to (Stratmann et al., 2003): $b_{\text {rel }}(z)=\frac{b(z)-\overline{b(z)}}{\overline{b(z)}}$, where $b(z)$ is the backscatter measured at the height $z$ and $\overline{b(z)}$ is the average backscatter at a specific height $z$ during the analyzed time period (06:00 a.m.-12:00 p.m. LST). A moving average filter of 5 min is applied and the vertical resolution is $20 \mathrm{~m}$. Panels in column 3 summarize normalized vertical temperature profiles $\left({ }^{\circ} \mathrm{C}\right)$ simulated by WRF during (g) event class A, (h) event class B and C, (i) non-event days between 14 and 26 May for times $t$ normalized relative to the hour of maximum rate change of $10 \mathrm{~nm}$ particle number concentrations. Temperatures in (g), (h) and (i) have been normalized relative to the ground value and different colors refer to different days.

mechanisms of these biases using model sensitivity analyses of:

- The initial particle loading. In order to investigate the model sensitivity to the initial PSD, we ran a simulation wherein UHMA was initialized using the measured PSD on 14 May and then left to run for the entire 14 day period. A consistent underestimation of growth rates remained (cf. Fig. 9a and b). An additional set of simulations was performed initializing the model with a PSD representative of "clear" atmospheric conditions as described by Seigneur et al. (1986) (Table 6). This ideal- ized PSD is applied as being representative of the lower backscatter associated with the residual layer. When this idealized PSD is used to initialize the UHMA model, the simulated nucleation intensity shows better accord with the observations (Table 1) and event class A growth rates are closer to the observed values, although a small negative bias in GR remains (Fig. 10 and Table 5). The intensity of nucleation is over-estimated relative to the ground-based measurements in simulations with the clear case PSD but this is rather consistent with nucleation occurring in a relatively shallow atmospheric layer 
Table 5. Measured and simulated growth rates $\left[\mathrm{nm} \mathrm{h}^{-1}\right.$ ] for class A events. Column 1 indicates the day in May 2008, column 2 the observed growth rates (GR) and column 3 shows simulated GR computed initializing the model with clear atmospheric conditions and setting 250 sections. Columns 4 and 5 refer to GR simulated initializing the model with measured PSD and setting 250 sections when the sulfuric acid $\left(\mathrm{H}_{2} \mathrm{SO}_{4}\right)$ and mass accommodation coefficient $(\alpha)$ correction are applied respectively, as described in Sect. 3.2. Columns 6-10 summarize the results from the sensitivity analysis of simulated growth rates on the number of sections $(20,80,150,250$ and 300 sections) when the model is initialized with measured PSD. The timing between measured and simulated maximum 6-30 nm particle number concentrations $\left(\Delta t=t_{\mathrm{obs}}-t_{\mathrm{sim}}\right)$, computed initializing the model each day with the measured PSD and with clear atmospheric conditions setting 250 sections, is also reported (columns 11-12).

\begin{tabular}{|c|c|c|c|c|c|c|c|c|c|c|c|}
\hline \multirow{4}{*}{ Day } & \multirow{4}{*}{$\begin{array}{l}\text { Observations } \\
\text { GR }\left(\mathrm{nm} \mathrm{h}^{-1}\right)\end{array}$} & \multicolumn{10}{|c|}{ Simulations } \\
\hline & & \multirow{3}{*}{$\begin{array}{r}\mathrm{GR}\left(\mathrm{nm} \mathrm{h}^{-1}\right): \\
\text { initialization } \\
\text { with clear case }\end{array}$} & \multicolumn{7}{|c|}{ GR $\left(\mathrm{nm} \mathrm{h}^{-1}\right)$ : initialization with measured PSD } & \multirow{3}{*}{$\begin{array}{l}\text { Initialization with measured PSD } \\
\qquad \Delta t(\mathrm{~h})\end{array}$} & \multirow{3}{*}{$\begin{array}{c}\text { Initialization with clear case } \\
\qquad \Delta t(\mathrm{~h})\end{array}$} \\
\hline & & & \multicolumn{7}{|c|}{ Number of sections } & & \\
\hline & & & $\begin{array}{r}\mathrm{H}_{2} \mathrm{SO}_{4} \\
\text { correction }\end{array}$ & $\alpha=0.43$ & 20 & 80 & 150 & 250 & 300 & & \\
\hline 17 & 1.87 & 2.09 & 1.43 & 0.84 & 0.46 & 0.70 & 0.77 & 0.79 & 0.78 & -1 & 2 \\
\hline 19 & 2.13 & 2.28 & 1.08 & 0.37 & 0.33 & 0.89 & 0.94 & 0.82 & 0.78 & -1 & 0 \\
\hline 21 & 3.16 & 2.03 & 1.67 & 0.64 & 0.34 & 0.51 & 0.52 & 0.52 & 0.52 & -2 & 0 \\
\hline 22 & 2.47 & 1.37 & 1.65 & 0.61 & 0.35 & 0.52 & 0.57 & 0.61 & 0.59 & -2 & 0 \\
\hline 24 & 3.73 & 2.42 & 1.97 & 0.85 & 0.53 & 0.85 & 0.91 & 0.91 & 0.92 & -2 & 1 \\
\hline 25 & 3.40 & 2.31 & 2.49 & 1.11 & 0.72 & 1.05 & 1.05 & 1.06 & 1.06 & -1 & 0 \\
\hline Mean & 2.79 & 2.08 & 1.72 & 0.74 & 0.46 & 0.75 & 0.79 & 0.79 & 0.78 & -1.5 & 0.5 \\
\hline
\end{tabular}

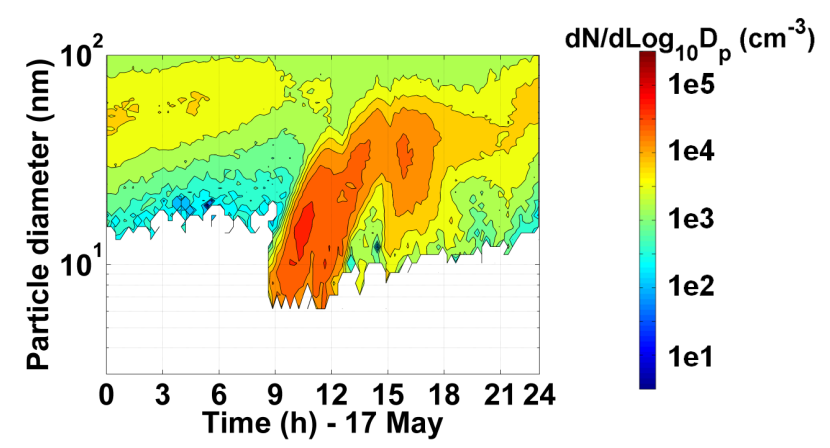

Fig. 7. Contour plot showing the particle number size distribution $\left[\mathrm{cm}^{-3}\right]$, expressed as $\mathrm{d} N / \mathrm{d} \log D_{\mathrm{p}}$, measured on 17 May. The presence of a closed contour line around the highest particle number concentrations may imply non-local nucleation (Birmili and Wiedensohler, 2000).

and then being mixed, diluted and reduced by coagulation during transport to the ground-based observing systems. However, initializing the model with clear atmospheric conditions also appears to overestimate formation rates during non-event days. Therefore we suggest that factors other than the initial particle loading may also play a major role in controlling nucleation occurrence.

- The availability of nucleation precursors. Since the kinetic approach assumes the nucleation rate is dependent on the square of sulfuric acid concentrations, part of the underestimation of simulated growth rates may be attributed to the negative bias in simulated sulfuric acid concentrations (Fig. 11). In the simulations, $\left[\mathrm{H}_{2} \mathrm{SO}_{4}\right]$ results from the reaction between sulfur diox- ide measured close to the ground and photochemically produced $\mathrm{OH}$. The chemical mechanism shows good skill in simulating $\mathrm{OH}$ concentrations relative to observations. The simulated average peak concentration during event class A days is $4.2 \times 10^{6} \mathrm{~cm}^{-3}$ compared to the observed value of $4 \times 10^{6} \mathrm{~cm}^{-3}$, whereas the average simulated maximum $[\mathrm{OH}]$ during non-event days is $2.7 \times 10^{6} \mathrm{~cm}^{-3}$, compared to measured value of $8 \times 10^{5} \mathrm{~cm}^{-3}$ (Pryor et al., 2011). Thus we speculate that the negative bias in simulated $\left[\mathrm{H}_{2} \mathrm{SO}_{4}\right]$ is due to a negative bias in $\mathrm{SO}_{2}$ concentrations due to their measurement below the forest canopy. To investigate if the systematic bias in $\left[\mathrm{H}_{2} \mathrm{SO}_{4}\right]$ was responsible for a negative bias in simulated nucleation an empirical correction factor (derived by fitting modeled $\left[\mathrm{H}_{2} \mathrm{SO}_{4}\right]$ to the observations, Fig. 11) was applied to the modeled values. Thus a simulation was conducted in which the model was initialized each day using the observed PSD and the concentration of $\left[\mathrm{H}_{2} \mathrm{SO}_{4}\right]$ was enhanced. The sensitivity analysis thus indicates the modeled GR increases from $30 \%$ to around $60 \%$ of observed values when the sulfuric acid correction is applied to match the measured values at the forest site (Table 5). This underestimation of growth rates even with enhanced $\left[\mathrm{H}_{2} \mathrm{SO}_{4}\right]$ is also observed when the model is initialized on May and left to run for the entire 14 day period (Fig. 12a).

- Another factor regulating the availability of condensable vapors and the growth rate of ultrafine particles is the mass accommodation coefficient which describes the probability of a gas molecule will stick to the preexisting particles. Mass accommodation coefficient values lower than 1 may thus enhance the concentration of condensable compounds available for nucleation hence 


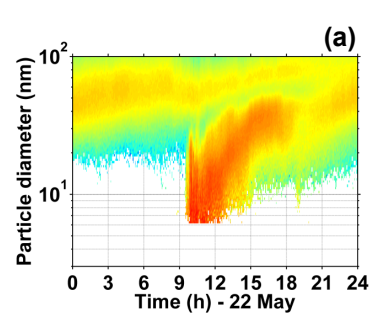

(c)

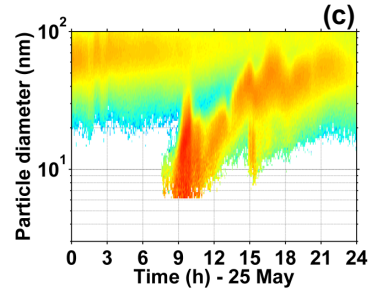

(e)

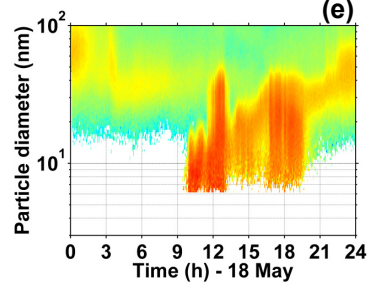

(g)

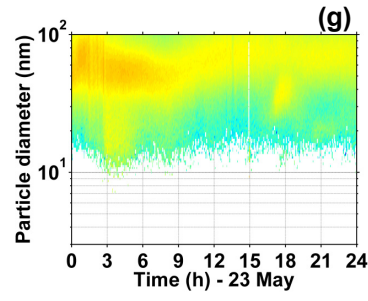

(b) $\left(\mathrm{cm}^{-3}\right)$

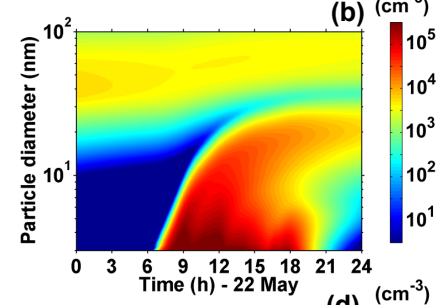

(d) $\left(\mathrm{cm}^{-3}\right)$

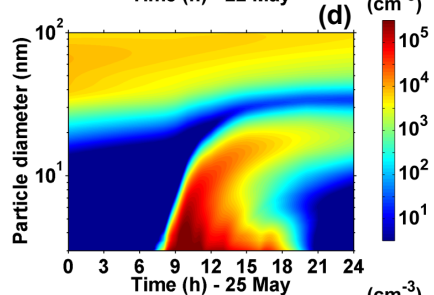

(f)
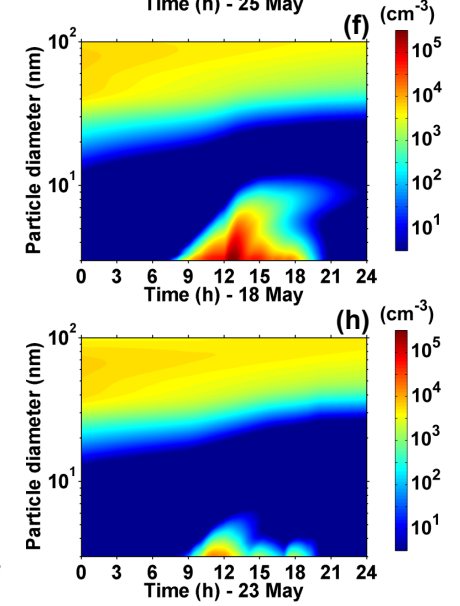

Fig. 8. Example particle number size distribution $\left[\mathrm{cm}^{-3}\right]$, expressed as $\mathrm{d} N / \mathrm{d} \log D_{\mathrm{p}}$ from measurements $(\mathbf{a}, \mathbf{c}, \mathbf{e}, \mathbf{g})$ and as simulated by the UHMA (b, d, f, h) during the NIFTy experiment. The reported days are representative of (a-b) an event class A and ( $\mathbf{g}-\mathbf{h})$ a nonevent day showing good model skill, (c-d) an event class A and (e-f) an event class $\mathrm{C}$ day in which particle growth is not captured by the model. Model simulations have been performed setting 250 sections in order to match the size resolution of the SMPS.

reducing the influence of the CS. When the mass accommodation coefficient was set to a value of 0.43 (based on work by Pöschl et al., 1998), UHMA simulations indicate only a weak sensitivity to this parameter (Fig. 12b and Table 5).

The role of organics both in nucleation and initial particle growth implied by the modeling presented herein may be an underestimate of the true contribution. However, a dominant role of inorganics in the initial growth is also supported by a mass closure experiment in which the concentration of $\mathrm{NH}_{4}^{+}$and $\mathrm{SO}_{4}^{2-}$ captured on a sizeresolved impactor accounted for the overwhelming majority of mass determined from the SMPS for $D_{\mathrm{p}} \leq$ $32 \mathrm{~nm}$ (Pryor et al., 2011), and also based on a scale analysis based on the work presented in Riccobono et
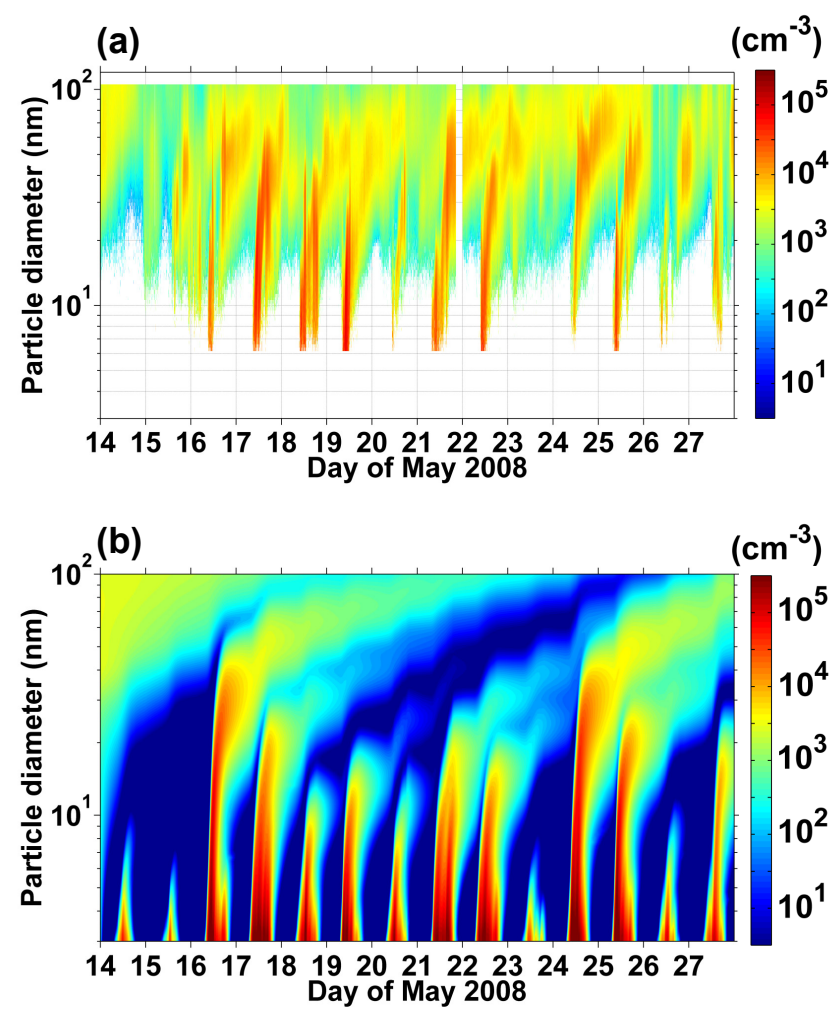

Fig. 9. Particle number size distribution $\left[\mathrm{cm}^{-3}\right]$, expressed as $\mathrm{d} N / \mathrm{d} \log D_{\mathrm{p}}$, (a) measured by the SMPS during the NIFTy experiment and (b) simulated. Model simulations have been performed setting 250 sections in order to match the size resolution of the SMPS and was initialized with the PSD observed on 14 May at 00:00 LST.

al. (2012), in which the estimated GR due to $\mathrm{H}_{2} \mathrm{SO}_{4}$ is given by:

$\mathrm{GR}_{\mathrm{est}}=\frac{K \times V_{\mathrm{sa}}}{\frac{\pi}{2} \times D_{\mathrm{p}}^{2}}$

where $K$ is the collision rate, $V_{\mathrm{sa}}$ is the volume of a sulfuric acid mole and $D_{\mathrm{p}}$ is the particle diameter. Using a seed particle diameter of $10 \mathrm{~nm}$, and the measured $\mathrm{H}_{2} \mathrm{SO}_{4}$ during the event class $\mathrm{A}$ days, $\mathrm{H}_{2} \mathrm{SO}_{4}$ alone is estimated to be responsible for an average $45 \%$ of the observed initial particle growth (although the range of variability is $23-99 \%$ ). To further examine the potential role of organics, we introduced the nucleation rate parameterization proposed in Metzger et al. (2010) into UHMA. This formulation takes into account the role played by both sulfuric acid and organics:

$J_{1}=K \times\left[\mathrm{H}_{2} \mathrm{SO}_{4}\right]^{m} \times[\mathrm{NucOrg}]^{n}$

where the prefactor $K$ was derived from kinetic theory and $m$ and $n$ were assumed to be 1 (Metzger et al., 2010). The average nucleation intensity simulated 
(a)

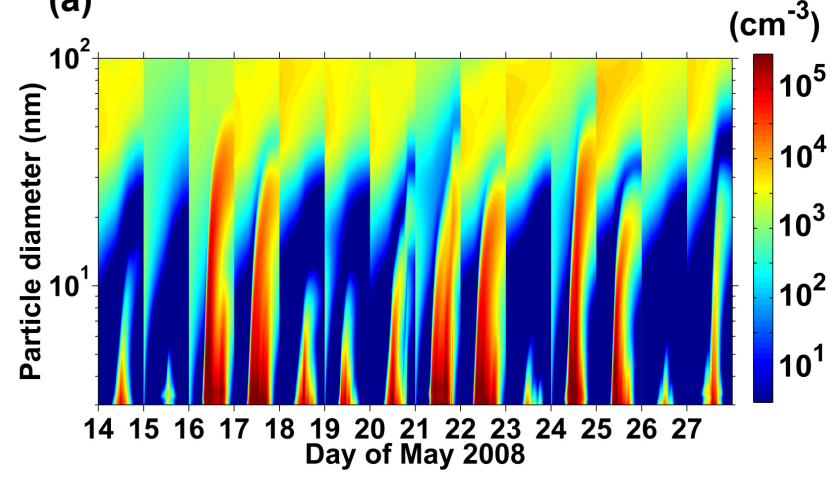

(b)

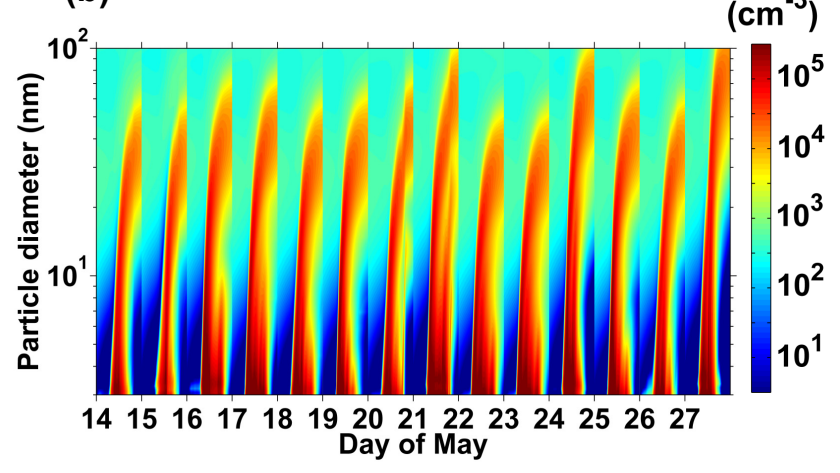

Fig. 10. Simulated particle number size distribution $\left[\mathrm{cm}^{-3}\right]$, expressed as $\mathrm{d} N / \mathrm{dLog} D_{\mathrm{p}}$. Model simulations were performed using 250 sections to match the size resolution of the SMPS. The model was initialized every day at 00:00 LST using (a) the measured PSD and (b) the PSD representative of clear atmospheric conditions as described in Seigneur et al. (1986).

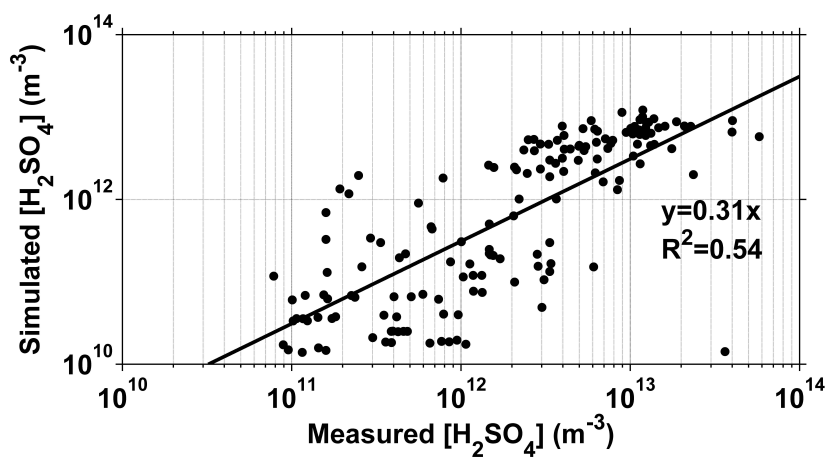

Fig. 11. Regression analysis between hourly averages of measured and simulated sulfuric acid concentrations $\left[\mathrm{H}_{2} \mathrm{SO}_{4}\right]\left(\mathrm{m}^{-3}\right)$ for event days during the NIFTy experiment. As shown, simulated values are negatively biased relative to the in situ measurements.

by this approach is $1.26 \times 10^{4} \mathrm{~cm}^{-3}$, which is much closer to the mean observed nucleation intensity (i.e. $5.86 \times 10^{4} \mathrm{~cm}^{-3}$ ) than the activation mechanism (where $J_{1}=10^{-8.87} \times\left[\mathrm{H}_{2} \mathrm{SO}_{4}\right]$ with the pre-factor derived from the data shown in Fig. 1) which gives a simulated nucle-

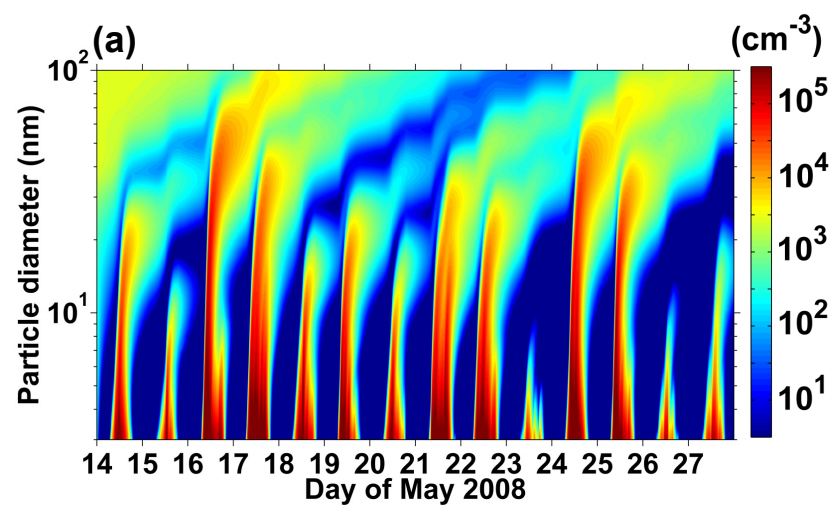

(b)

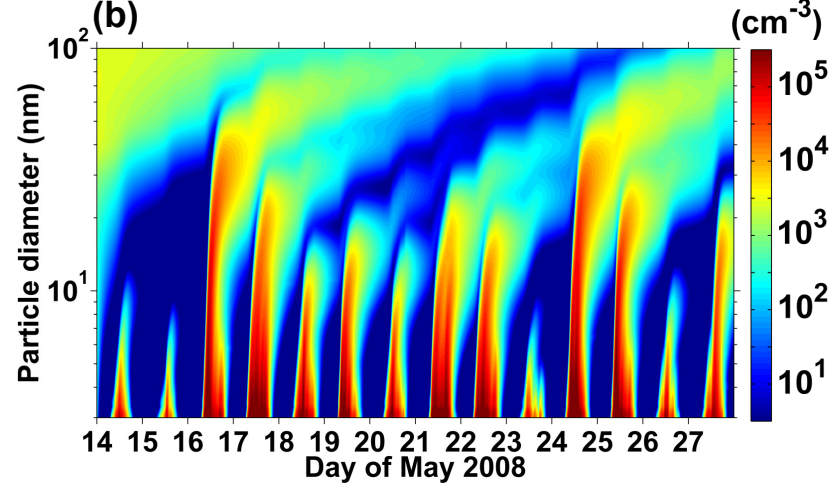

Fig. 12. Simulated particle number size distribution $\left[\mathrm{cm}^{-3}\right]$, expressed as $\mathrm{d} N / \mathrm{d} \log D_{\mathrm{p}}$ showing model sensitivity on (a) sulfuric acid concentrations which have been enhanced by a factor 3.2 in order to match the observed values and (b) on the mass accommodation coefficient, set to 0.43 for each condensable compound (Pöschl et al., 1998). Model simulations have been performed setting 250 sections in order to match the size resolution of the SMPS and initialized with the PSD observed on 14 May at 00:00 LST.

ation intensity of $4.26 \times 10^{2} \mathrm{~cm}^{-3}$. However, the parameterization shown in Eq. (9) results in an average nucleation intensity value that is lower than that simulated by the kinetic mechanism for event class A days (i.e. $1.56 \times 10^{4} \mathrm{~cm}^{-3}$ ). These analyses are thus supportive of the inference that the organics do not play a dominant role in controlling nucleation occurrence, the formation of the critical clusters and the initial stages of particle growth, which is consistent with an elevated nucleation source.

\section{Discussion and concluding remarks}

In this study we provide independent evidence, both from observations and modeling results, supporting the hypothesis of an elevated source of nucleation in the residual layer, as also advanced at other sites (Boulon et al., 2011; Pierce et al., 2012; Stratmann et al., 2003). Evidence in support of this postulate derived from observations at the MMSF site located 
Table 6. Initial conditions of geometric mean diameter $[\mu \mathrm{m}]$, standard deviation and number concentration [ $\mathrm{cm}^{-3}$ ] for each mode of the PSD associated with clear atmospheric conditions and the average of observed PSD from the FMPS measurements.

\begin{tabular}{llll|lll}
\hline Property & \multicolumn{3}{c}{ Clear Case } & \multicolumn{3}{c}{ Measurements } \\
\cline { 2 - 7 } & Aitken & Accumulation & Coarse & Aitken & Accumulation & Coarse \\
\hline Geometric mean diameter $[\mu \mathrm{m}]$ & 0.021 & 0.103 & 0.929 & 0.058 & 0.026 & 1.107 \\
Standard Deviation & 1.80 & 1.60 & 2.20 & 1.67 & 1.48 & 2.20 \\
Number Concentration $\left[\mathrm{cm}^{-3}\right]$ & $1.256 \times 10^{3}$ & $6.451 \times 10^{2}$ & $7.252 \times 10^{-1}$ & $7.664 \times 10^{3}$ & $1.965 \times 10^{3}$ & $2.920 \times 10^{2}$ \\
\hline
\end{tabular}

in southern Indiana and thus within the polluted Ohio River Valley include:

- There is a clear relationship between the occurrence of elevated ultrafine particle concentrations and enhancement of turbulence intensity consistent with erosion of the nocturnal boundary layer and vertical transfer of recently nucleated particles (Fig. 4).

- The absence of a relationship between the near-surface condensational sink one hour prior to the appearance of significant ultrafine particle concentrations and concentrations of sub 10-nm particles (Fig. 5). Based on backscatter data from a ceilometer, atmospheric conditions more favorable to new particle formation (i.e. lower CS) are found in the residual layer (Fig. 6).

- The primary distinction between event and non-event days, in terms of boundary layer dynamics, is the consistent presence of a capping inversion on event class A days which is always eroded by the time of nucleation observation in the surface layer (Fig. 6g). This modeling evidence strongly supports the hypothesis of new particles formed in the residual layer and then mixed down to the surface layer with the erosion of the nocturnal inversion.

- The low ratio between $3 \mathrm{~nm}$ and $6 \mathrm{~nm}$ particle number concentrations measured in the near-surface layer at the MMSF site may be the result of an early aging of freshly nucleated particles before detection during their advection from higher atmospheric levels to the mixed layer.

Model sensitivity analyses indicate nucleation rates appear to be highly dependent on the PSD used to initialize the simulations with generally lower sensitivity to $\mathrm{H}_{2} \mathrm{SO}_{4}$ availability, the mass accommodation coefficient and the number of sections used to represent the PSD. Thus results from the UHMA simulations that also support the postulate that nucleation is not occurring in the near-surface layer include the following:

- The base case simulations with UHMA, driven by the PSD measured at $46 \mathrm{~m}$ and sulfur dioxide concentrations measured close to the surface, indicate consistent underestimation of nucleation intensities and growth rates (Figs. 8, 9 and 10, and Tables 1 and 5). Higher agreement between observed and simulated PSD is obtained when the initial PSD is set to conditions representative of clear atmospheric conditions (Fig. 10b) and when higher sulfuric acid concentrations are applied (Fig. 12a). Both of these conditions may be found at higher levels in the atmosphere and thus lead to inference that nucleation is initiated aloft and the newly formed particles are then mixed downward with the breaking of the residual layer and formation of the convective boundary layer (Pierce et al., 2012; Stratmann et al., 2003; Wehner et al., 2010).

- The time at which simulated peak number concentrations in the size range of 6-30 nm occur is on average shifted towards an earlier nucleation start when assuming clear atmospheric conditions. This result supports our hypothesis of new particles formed aloft (e.g. in the residual layer), then mixed down and diluted with the formation of the mixed layer (thus also explaining the slightly lower observed nucleation intensities compared to simulated values). The greatest temporal gradient (i.e. rate change) of 6-10 nm particle number concentrations occurs in the hour prior to the maximum in near-surface observations which is also consistent with the postulate that nucleation occurs aloft and also implies an essential role for boundary layer dynamics in observations of elevated ultrafine particle concentrations in the surface layer.

Although the postulates and findings advanced here cannot be considered conclusive, they are consistent with prior research that has indicated that new particle formation likely occurs principally at or close to the residual layer (or free troposphere) (Boulon et al., 2011; Lauros et al., 2011; Pierce et al., 2012; Stratmann et al., 2003; Wehner et al., 2010). Given the key role played by boundary layer dynamics and the location of the capping inversion in dictating the occurrence of high particle concentrations near the surface, findings from this study may provide insights for the vertical resolution required by regional models to adequately represent aerosol dynamics. 
Acknowledgements. This research was funded by grants to SCP from NSF (0544745 and 1102309). Some of the meteorological data used herein were collected under funding from the Office of Science (BER), US Department of Energy, grant DE-FG0207ER64371, and additional funding from the IU Pervasive Technology Institute was also provided. TP acknowledges funding from the Academy of Finland (139656). Thanks to our research collaborators B. Plale (IU) and A. Rossner (Clarkson). Jim Smith is acknowledged for providing the $\mathrm{SO}_{2}$ instrument. Lee Mauldin and Joshua McGrath are acknowledged for setting up and operating the CIMS instrument. Comments from external reviewers improved this manuscript and are gratefully acknowledged.

Edited by: N. Riemer

\section{References}

Birmili, W. and Wiedensohler, A.: New particle formation in the continental boundary layer: Meteorological and gas phase parameter influence, Geophys. Res. Lett., 27, 3325-3328, doi:10.1029/1999gl011221, 2000.

Boulon, J., Sellegri, K., Hervo, M., Picard, D., Pichon, J.-M., Fréville, P., and Laj, P.: Investigation of nucleation events vertical extent: a long term study at two different altitude sites, Atmos. Chem. Phys., 11, 5625-5639, doi:10.5194/acp-11-56252011, 2011.

Boy, M. and Kulmala, M.: Nucleation events in the continental boundary layer: Influence of physical and meteorological parameters, Atmos. Chem. Phys., 2, 1-16, doi:10.5194/acp-2-1-2002, 2002.

Boy, M., Kulmala, M., Ruuskanen, T. M., Pihlatie, M., Reissell, A., Aalto, P. P., Keronen, P., Dal Maso, M., Hellen, H., Hakola, H., Jansson, R., Hanke, M., and Arnold, F.: Sulphuric acid closure and contribution to nucleation mode particle growth, Atmos. Chem. Phys., 5, 863-878, doi:10.5194/acp-5-863-2005, 2005.

Boy, M., Hellmuth, O., Korhonen, H., Nilsson, E. D., ReVelle, D., Turnipseed, A., Arnold, F., and Kulmala, M.: MALTE - model to predict new aerosol formation in the lower troposphere, Atmos. Chem. Phys., 6, 4499-4517, doi:10.5194/acp-6-4499-2006, 2006.

Crumeyrolle, S., Manninen, H. E., Sellegri, K., Roberts, G., Gomes, L., Kulmala, M., Weigel, R., Laj, P., and Schwarzenboeck, A.: New particle formation events measured on board the ATR-42 aircraft during the EUCAARI campaign, Atmos. Chem. Phys., 10, 6721-6735, doi:10.5194/acp-10-6721-2010, 2010.

Dal Maso, M., Kulmala, M., Lehtinen, K. E. J., Makela, J. M., Aalto, P., and O'Dowd, C. D.: Condensation and coagulation sinks and formation of nucleation mode particles in coastal and boreal forest boundary layers, J. Geophys. Res.-Atmos., 107, 8097, doi:10.1029/2001jd001053, 2002.

Eisele, F. L. and Tanner, D. J.: Measurement of the gas-phase concentration of $\mathrm{H}_{2} \mathrm{SO}_{4}$ and methane sulphonic-acid and estimates of $\mathrm{H}_{2} \mathrm{SO}_{4}$ production and loss in the atmosphere, J. Geophys. Res., 98, 9001-9010, 1993.

Griffin, R. J., Nguyen, K., Dabdub, D., and Seinfeld, J. H.: A coupled hydrophobic-hydrophilic model for predicting secondary organic aerosol formation, J. Atmos. Chem., 44, 171190, doi:10.1023/a:1022436813699, 2003.
Grosjean, D.: In situ organic aerosol formation during a smog episode: Estimated production and chemical functionality, Atmos. Environ., 26, 953-963, doi:10.1016/0960-1686(92)90027i, 1992 .

Hertel, O., Berkowicz, R., Christensen, J., and Hov, O.: Test of two numerical schemes for use in atmospheric transport-chemistry models, Atmos. Environ., 27, 2591-2611, doi:10.1016/09601686(93)90032-t, 1993.

Hu, X.-M., Nielsen-Gammon, J. W., and Zhang, F.: Evaluation of three planetary boundary layer schemes in the wrf model, J. Appl. Meteorol. Climatol., 49, 1831-1844, doi:10.1175/2010jamc2432.1, 2010.

Jacobson, M. Z. and Turco, R. P.: Simulating condensational growth, evaporation, and coagulation of aerosols using a combined moving and stationary size grid, Aerosol Sci. Technol., 22, 73-92, doi:10.1080/02786829408959729, 1995.

Korhonen, H., Lehtinen, K. E. J., and Kulmala, M.: Multicomponent aerosol dynamics model UHMA: model development and validation, Atmos. Chem. Phys., 4, 757-771, doi:10.5194/acp-4757-2004, 2004.

Kuang, C., McMurry, P. H., McCormick, A. V., and Eisele, F. L.: Dependence of nucleation rates on sulfuric acid vapor concentration in diverse atmospheric locations, J. Geophys. Res., 113, D10209, doi:10.1029/2007jd009253, 2008.

Kulmala, M., Dal Maso, M., Makela, J. M., Pirjola, L., Vakeva, M., Aalto, P., Miikkulainen, P., Hameri, K., and O'Dowd, C. D.: On the formation, growth and composition of nucleation mode particles, Tellus B, 53, 479-490, doi:10.1034/j.16000889.2001.530411.x, 2001.

Kulmala, M., Asmi, A., Lappalainen, H. K., Baltensperger, U., Brenguier, J.-L., Facchini, M. C., Hansson, H.-C., Hov, Ø., O'Dowd, C. D., Pöschl, U., Wiedensohler, A., Boers, R., Boucher, O., de Leeuw, G., Denier van der Gon, H. A. C., Feichter, J., Krejci, R., Laj, P., Lihavainen, H., Lohmann, U., McFiggans, G., Mentel, T., Pilinis, C., Riipinen, I., Schulz, M., Stohl, A., Swietlicki, E., Vignati, E., Alves, C., Amann, M., Ammann, M., Arabas, S., Artaxo, P., Baars, H., Beddows, D. C. S., Bergström, R., Beukes, J. P., Bilde, M., Burkhart, J. F., Canonaco, F., Clegg, S. L., Coe, H., Crumeyrolle, S., D’Anna, B., Decesari, S., Gilardoni, S., Fischer, M., Fjaeraa, A. M., Fountoukis, C., George, C., Gomes, L., Halloran, P., Hamburger, T., Harrison, R. M., Herrmann, H., Hoffmann, T., Hoose, C., Hu, M., Hyvärinen, A., Hõrrak, U., Iinuma, Y., Iversen, T., Josipovic, M., Kanakidou, M., Kiendler-Scharr, A., Kirkevåg, A., Kiss, G., Klimont, Z., Kolmonen, P., Komppula, M., Kristjánsson, J.-E., Laakso, L., Laaksonen, A., Labonnote, L., Lanz, V. A., Lehtinen, K. E. J., Rizzo, L. V., Makkonen, R., Manninen, H. E., McMeeking, G., Merikanto, J., Minikin, A., Mirme, S., Morgan, W. T., Nemitz, E., O’Donnell, D., Panwar, T. S., Pawlowska, H., Petzold, A., Pienaar, J. J., Pio, C., Plass-Duelmer, C., Prévôt, A. S. H., Pryor, S., Reddington, C. L., Roberts, G., Rosenfeld, D., Schwarz, J., Seland, Ø., Sellegri, K., Shen, X. J., Shiraiwa, M., Siebert, H., Sierau, B., Simpson, D., Sun, J. Y., Topping, D., Tunved, P., Vaattovaara, P., Vakkari, V., Veefkind, J. P., Visschedijk, A., Vuollekoski, H., Vuolo, R., Wehner, B., Wildt, J., Woodward, S., Worsnop, D. R., van Zadelhoff, G.-J., Zardini, A. A., Zhang, K., van Zyl, P. G., Kerminen, V.-M., S Carslaw, K., and Pandis, S. N.: General overview: European Integrated project on Aerosol Cloud Climate and Air Quality interactions 
(EUCAARI) - integrating aerosol research from nano to global scales, Atmos. Chem. Phys., 11, 13061-13143, doi:10.5194/acp11-13061-2011, 2011.

Laaksonen, A., Kulmala, M., O’Dowd, C. D., Joutsensaari, J., Vaattovaara, P., Mikkonen, S., Lehtinen, K. E. J., Sogacheva, L., Dal Maso, M., Aalto, P., Petäjä, T., Sogachev, A., Yoon, Y. J., Lihavainen, H., Nilsson, D., Facchini, M. C., Cavalli, F., Fuzzi, S., Hoffmann, T., Arnold, F., Hanke, M., Sellegri, K., Umann, B., Junkermann, W., Coe, H., Allan, J. D., Alfarra, M. R., Worsnop, D. R., Riekkola, M. -L., Hyötyläinen, T., and Viisanen, Y.: The role of VOC oxidation products in continental new particle formation, Atmos. Chem. Phys., 8, 2657-2665, doi:10.5194/acp-82657-2008, 2008.

Lauros, J., Sogachev, A., Smolander, S., Vuollekoski, H., Sihto, S.L., Mammarella, I., Laakso, L., Rannik, Ü., and Boy, M.: Particle concentration and flux dynamics in the atmospheric boundary layer as the indicator of formation mechanism, Atmos. Chem. Phys., 11, 5591-5601, doi:10.5194/acp-11-5591-2011, 2011.

Lehtinen, K. E. J. and Kulmala, M.: A model for particle formation and growth in the atmosphere with molecular resolution in size, Atmos. Chem. Phys., 3, 251-257, doi:10.5194/acp-3-251-2003, 2003.

Mauldin, R. L., Cantrell, C. A., Zondlo, M. A., Kosciuch, E., Ridley, B. A., Weber, R., and Eisele, F. E.: Measurements of $\mathrm{OH}, \mathrm{H}_{2} \mathrm{SO}_{4}$, and MSA during tropospheric ozone production about the spring equinox (TOPSE), J. Geophys. Res., 108, 8366, doi:10.1029/2002jd002295, 2003.

Metzger, A., Verheggen, B., Dommen, J., Duplissy, J., Prevot, A. S. H., Weingartner, E., Riipinen, I., Kulmala, M., Spracklen, D. V., Carslaw, K. S., and Baltensperger, U.: Evidence for the role of organics in aerosol particle formation under atmospheric conditions, P. Natl. Acad. Sci. USA, 107, 6646-6651, doi:10.1073/pnas.0911330107, 2010.

Nilsson, E. D., Rannik, U., Kulmala, M., Buzorius, G., and O'Dowd, C. D.: Effects of continental boundary layer evolution, convection, turbulence and entrainment, on aerosol formation, Tellus B, 53, 441-461, doi:10.1034/j.1600-0889.2001.530409.x, 2001.

Petäjä, T., Mauldin, III, R. L., Kosciuch, E., McGrath, J., Nieminen, T., Paasonen, P., Boy, M., Adamov, A., Kotiaho, T., and Kulmala, M.: Sulfuric acid and $\mathrm{OH}$ concentrations in a boreal forest site, Atmos. Chem. Phys., 9, 7435-7448, doi:10.5194/acp9-7435-2009, 2009.

Pierce, J. R., Leaitch, W. R., Liggio, J., Westervelt, D. M., Wainwright, C. D., Abbatt, J. P. D., Ahlm, L., Al-Basheer, W., Cziczo, D. J., Hayden, K. L., Lee, A. K. Y., Li, S.-M., Russell, L. M., Sjostedt, S. J., Strawbridge, K. B., Travis, M., Vlasenko, A., Wentzell, J. J. B., Wiebe, H. A., Wong, J. P. S., and Macdonald, A. M.: Nucleation and condensational growth to CCN sizes during a sustained pristine biogenic SOA event in a forested mountain valley, Atmos. Chem. Phys., 12, 3147-3163, doi:10.5194/acp-12-3147-2012, 2012.

Pöschl, U., Canagaratna, M., Jayne, J. T., Molina, L. T., Worsnop, D. R., Kolb, C. E., and Molina, M. J.: Mass accommodation coefficient of $\mathrm{H}_{2} \mathrm{SO}_{4}$ vapor on aqueous sulfuric acid surfaces and gaseous diffusion coefficient of $\mathrm{H}_{2} \mathrm{SO}_{4}$ in $\mathrm{N}_{2} / \mathrm{H}_{2} \mathrm{O}$, J. Phys. Chem. A, 102, 10082-10089, doi:10.1021/jp982809s, 1998.

Pryor, S. C. and Binkowski, F. S.: An analysis of the time scales associated with aerosol processes during dry deposition, Aerosol
Sci. Technol., 38, 1091-1098, doi:10.1080/027868290885827, 2004.

Pryor, S. C., Barthelmie, R. J., Sørensen, L., and Jensen, B.: Ammonia concentrations and fluxes over a forest in the Midwestern USA, Atmos. Environ., 35, 5645-5656, 2001.

Pryor, S. C., Barthelmie, R. J., Spaulding, A. M., Larsen, S. E., and Petroff, A.: Size-resolved fluxes of sub-100$\mathrm{nm}$ particles over forests, J. Geophys. Res., 114, D18212, doi:10.1029/2009jd012248, 2009.

Pryor, S. C., Spaulding, A. M., and Barthelmie, R. J.: New particle formation in the midwestern USA: Event characteristics, meteorological context and vertical profiles, Atmos. Environ., 44, 4413-4425, doi:10.1016/j.atmosenv.2010.07.045, 2010.

Pryor, S. C., Barthelmie, R. J., Sørensen, L. L., McGrath, J. G., Hopke, P., and Petäjä, T.: Spatial and vertical extent of nucleation events in the Midwestern USA: insights from the Nucleation In ForesTs (NIFTy) experiment, Atmos. Chem. Phys., 11, 16411657, doi:10.5194/acp-11-1641-2011, 2011.

Rannik, U., Aalto, P., Keronen, P., Vesala, T., and Kulmala, M.: Interpretation of aerosol particle fluxes over a pine forest: Dry deposition and random errors, J. Geophys. Res., 108, 4544, doi:10.1029/2003jd003542, 2003.

Riccobono, F., Rondo, L., Sipilä, M., Barmet, P., Curtius, J., Dommen, J., Ehn, M., Ehrhart, S., Kulmala, M., Kürten, A., Mikkilä, J., Petäjä, T., Weingartner, E., and Baltensperger, U.: Contribution of sulfuric acid and oxidized organic compounds to particle formation and growth, Atmos. Chem. Phys. Discuss., 12, 1135111389, doi:10.5194/acpd-12-11351-2012, 2012.

Seigneur, C., Hudischewskyj, A. B., Seinfeld, J. H., Whitby, K. T., Whitby, E. R., Brock, J. R., and Barnes, H. M.: Simulation of aerosol dynamics - a comparative review of mathematical models, Aerosol Sci. Technol., 5, 205-222, doi:10.1080/02786828608959088, 1986.

Seinfeld, J. H. and Pandis, S. N.: Atmospheric chemistry and physics - from air pollution to climate change (2nd edition), John Wiley \& Sons, 2006.

Sihto, S.-L., Kulmala, M., Kerminen, V.-M., Dal Maso, M., Petäjä, T., Riipinen, I., Korhonen, H., Arnold, F., Janson, R., Boy, M., Laaksonen, A., and Lehtinen, K. E. J.: Atmospheric sulphuric acid and aerosol formation: implications from atmospheric measurements for nucleation and early growth mechanisms, Atmos. Chem. Phys., 6, 4079-4091, doi:10.5194/acp-6-4079-2006, 2006.

Sihto, S.-L., Vuollekoski, H., Leppä, J., Riipinen, I., Kerminen, V.M., Korhonen, H., Lehtinen, K. E. J., Boy, M., and Kulmala, M.: Aerosol dynamics simulations on the connection of sulphuric acid and new particle formation, Atmos. Chem. Phys., 9, 29332947, doi:10.5194/acp-9-2933-2009, 2009.

Simpson, D., Olendrzynski, K., Semb, A., Støren, E., and Unger, S.: Photochemical oxidant modelling in Europe; multi-annual modelling and source-receptor relationships, EMEP/MSC-W3/97, 1997.

Skamarock, W. C., Klemp, J. B., Dudhia, J., Gill, D. O., Barker, D. M., Duda, M. G., Huang, X.-Y., Wang, W., and Powers, J. G.: A description of the advanced research WRF version 3, National Center for Atmospheric Research, Boulder, Colorado, USA, 2008.

Slinn, W. G. N.: Predictions for particle deposition to vegetative canopies, Atmos. Environ., 16, 1785-1794, doi:10.1016/0004- 
6981(82)90271-2, 1982.

Spracklen, D. V., Pringle, K. J., Carslaw, K. S., Chipperfield, M. P., and Mann, G. W.: A global off-line model of sizeresolved aerosol microphysics: I. Model development and prediction of aerosol properties, Atmos. Chem. Phys., 5, 22272252, doi:10.5194/acp-5-2227-2005, 2005.

Spracklen, D. V., Carslaw, K. S., Kulmala, M., Kerminen, V.-M., Mann, G. W., and Sihto, S.-L.: The contribution of boundary layer nucleation events to total particle concentrations on regional and global scales, Atmos. Chem. Phys., 6, 5631-5648, doi:10.5194/acp-6-5631-2006, 2006.

Stratmann, F., Siebert, H., Spindler, G., Wehner, B., Althausen, D., Heintzenberg, J., Hellmuth, O., Rinke, R., Schmieder, U., Seidel, C., Tuch, T., Uhrner, U., Wiedensohler, A., Wandinger, U., Wendisch, M., Schell, D., and Stohl, A.: New-particle formation events in a continental boundary layer: first results from the SATURN experiment, Atmos. Chem. Phys., 3, 1445-1459, doi:10.5194/acp-3-1445-2003, 2003.

Wehner, B., Siebert, H., Stratmann, F., Tuch, T., Wiedensohler, A., Petaja, T., Dal Maso, M., and Kulmala, M.: Horizontal homogeneity and vertical extent of new particle formation events, Tellus B, 59, 362-371, doi:10.1111/j.1600-0889.2007.00260.x, 2007.
Wehner, B., Siebert, H., Ansmann, A., Ditas, F., Seifert, P., Stratmann, F., Wiedensohler, A., Apituley, A., Shaw, R. A., Manninen, H. E., and Kulmala, M.: Observations of turbulence-induced new particle formation in the residual layer, Atmos. Chem. Phys., 10, 4319-4330, doi:10.5194/acp-10-4319-2010, 2010.

Zhang, Y., Seigneur, C., Seinfeld, J. H., Jacobson, M. Z., and Binkowski, F. S.: Simulation of aerosol dynamics: A comparative review of algorithms used in air quality models, Aerosol Sci. Technol., 31, 487-514, doi:10.1080/027868299304039, 1999.

Zhang, Y., Liu, P., Liu, X.-H., Jacobson, M. Z., McMurry, P. H., Yu, F., Yu, S., and Schere, K. L.: A comparative studyof nucleation parameterizations: 2. Three-dimensional model application and evaluation, J. Geophys. Res., 115, D20213, doi:10.1029/2010jd014151, 2010a.

Zhang, Y., McMurry, P. H., Yu, F., and Jacobson, M. Z.: A comparative study of nucleation parameterizations: 1. Examination and evaluation of the formulations, J. Geophys. Res., 115, D20212, doi:10.1029/2010jd014150, 2010b. 